USGS Greater Everglades Priority Ecosystems Science Program

Prepared in cooperation with the U.S. Army Corps of Engineers

\title{
The Everglades Depth Estimation Network (EDEN) Surface-Water Interpolation Model, Version 3
}

Scientific Investigations Report 2020-5083 
Cover. Shark River Slough from the Shark Valley observation tower. Photograph courtesy of G. DeFalco, National Park Service. 


\section{The Everglades Depth Estimation Network (EDEN) Surface-Water Interpolation Model, Version 3}

By Saira Haider, Eric Swain, James Beerens, Matthew Petkewich, Bryan McCloskey, and Heather Henkel

USGS Greater Everglades Priority Ecosystems Science Program

Prepared in cooperation with the U.S. Army Corps of Engineers

Scientific Investigations Report 2020-5083 


\title{
U.S. Department of the Interior \\ DAVID BERNHARDT, Secretary
}

\author{
U.S. Geological Survey \\ James F. Reilly II, Director
}

U.S. Geological Survey, Reston, Virginia: 2020

For more information on the USGS - the Federal source for science about the Earth, its natural and living resources, natural hazards, and the environment—visit https://www.usgs.gov or call 1-888-ASK-USGS.

For an overview of USGS information products, including maps, imagery, and publications, visit https://store.usgs.gov/.

Any use of trade, firm, or product names is for descriptive purposes only and does not imply endorsement by the U.S. Government.

Although this information product, for the most part, is in the public domain, it also may contain copyrighted materials as noted in the text. Permission to reproduce copyrighted items must be secured from the copyright owner.

Suggested citation:

Haider, S., Swain, E., Beerens, J., Petkewich, M., McCloskey, B., and Henkel, H., 2020, The Everglades Depth Estimation Network (EDEN) surface-water interpolation model, version 3: U.S. Geological Survey Scientific Investigations Report 2020-5083, 31 p., https://doi.org/10.3133/sir20205083.

ISSN 2328-0328 (online) 


\section{Acknowledgments}

The authors thank Donna George, Gretchen Ehlinger, and Angela Dunn at the U.S. Army Corps of Engineers for their continued support of the Everglades Depth Estimation Network (EDEN) and its ongoing advancements.

The authors would like to remember and honor the late Paul Conrads of the U.S. Geological Survey, who provided invaluable support and innovations to the EDEN project for many years. U.S. Geological Survey colleagues Leonard Pearlstine and Jeremy Decker provided substantive reviews of an early draft of this report. 



\section{Contents}

Acknowledgments ……...................................................................................................................

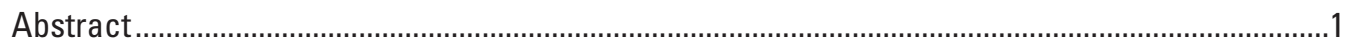

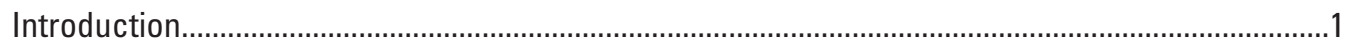

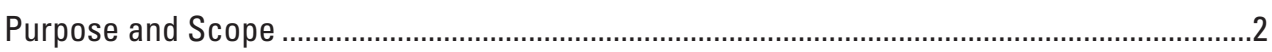

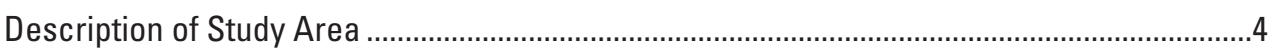

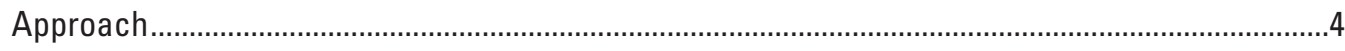

Changes in Field Gages and Conditions.............................................................................

Radial Basis Function Interpolation in the EDEN V3 Model .....................................................

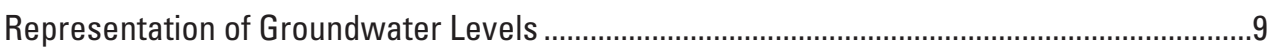

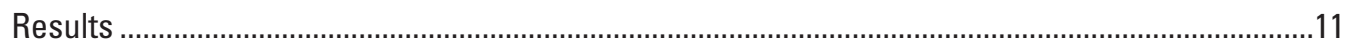

Accuracy Assessment of EDEN V3 Model and Comparison to V2 ........................................11

Validation for Accuracy Assessment With Benchmarks (Field Data) ..............................11

Consistency Between EDEN V3 and V2 Models.........................................................11

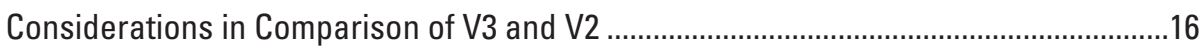

Representing Groundwater Levels .................................................................................16

Summary and Conclusions...................................................................................................

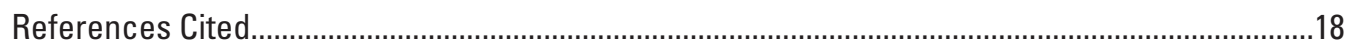

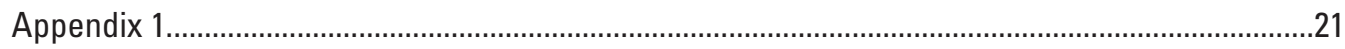

\section{Figures}

1. Map showing Everglades Depth Estimation Network (EDEN) model domain, management regions, and location of EDEN water-level gaging stations used in the EDEN surface-water model, version 3 .

2. Map showing vegetation of southern Florida circa 1943 and the Everglades Depth Estimation Network model domain

3. Maps of the Everglades showing flow directions before drainage and after drainage and compartmentalization.

4. Map showing eight subdomains used in the Everglades Depth Estimation Network version 3 model.

5. Map of the border between NPS and L67ext subdomains showing decreasing influence of the $\mathrm{L} 67$ canal extension with decreasing latitude

6. Map showing water-level surface on July 20, 2019, from the Everglades Depth Estimation Network surface-water interpolation model, version 3

7. Map showing locations of the Florida Department of Environmental Protection and U.S. Army Corps of Engineers elevation benchmarks in the Everglades Depth Estimation Network model domain

8. Map showing root mean square difference between water surfaces interpolated by the Everglades Depth Estimation Network version 2 and version 3 models from April 1, 2014, to March 31, 2018

9. Map showing standard deviation between water surfaces interpolated by the Everglades Depth Estimation Network version 2 and version 3 models from April 1, 2014, to March 31, 2018.

10. Maps showing comparison of water levels in Water Conservation Areas $2 A$ and 2B on May 15, 2009, using the Everglades Depth Estimation Network version 3 model. 


\section{Tables}

1. Radial basis function parameter values for the Everglades Depth Estimation Network version 3 and version 2 models.

1.1 Water-level gages used in Everglades Depth Estimation Network surfacewater model versions 2 and 3 including pseudogages used for interpolation that do not exist on the ground.

\section{Conversion Factors}

U.S. customary units to International System of Units

\begin{tabular}{|c|c|c|}
\hline Multiply & By & To obtain \\
\hline \multicolumn{3}{|c|}{ Length } \\
\hline inch (in.) & 2.54 & centimeter $(\mathrm{cm})$ \\
\hline inch (in.) & 25.4 & millimeter (mm) \\
\hline foot $(\mathrm{ft})$ & 0.3048 & meter (m) \\
\hline mile (mi) & 1.609 & kilometer (km) \\
\hline \multicolumn{3}{|c|}{ Area } \\
\hline acre & 4,047 & square meter $\left(\mathrm{m}^{2}\right)$ \\
\hline acre & 0.4047 & hectare (ha) \\
\hline acre & 0.4047 & square hectometer $\left(\mathrm{hm}^{2}\right)$ \\
\hline acre & 0.004047 & square kilometer $\left(\mathrm{km}^{2}\right)$ \\
\hline square mile $\left(\mathrm{mi}^{2}\right)$ & 259.0 & hectare (ha) \\
\hline square mile $\left(\mathrm{mi}^{2}\right)$ & 2.590 & square kilometer $\left(\mathrm{km}^{2}\right)$ \\
\hline
\end{tabular}

\section{Datum}

Vertical coordinate information is referenced to the North American Vertical Datum of 1988 (NAVD 88).

Horizontal coordinate information is referenced to the North American Datum of 1983 (NAD 83).

Elevation, as used in this report, refers to distance above the vertical datum. 


\section{Abbreviations}

$\begin{array}{ll}\text { BCNP } & \text { Big Cypress National Preserve } \\ \text { CERP } & \text { Comprehensive Everglades Restoration Plan } \\ \text { EDEN } & \text { Everglades Depth Estimation Network } \\ \text { ENP } & \text { Everglades National Park } \\ \text { EVE } & \text { Explore and View EDEN } \\ \text { PW } & \text { Pennsuco Wetlands [model subdomain] } \\ \text { RBF } & \text { radial basis function } \\ \text { RECOVER } & \text { REstoration COordination and VERification } \\ \text { RMSD } & \text { root mean square difference } \\ \text { RMSE } & \text { root mean square error } \\ \text { SD } & \text { standard deviation } \\ \text { USGS } & \text { U.S. Geological Survey } \\ \text { V1 } & \text { version 1 } \\ \text { V2 } & \text { version } 2 \\ \text { V3 } & \text { version } 3 \\ \text { WCA } & \text { water conservation area }\end{array}$





\title{
The Everglades Depth Estimation Network (EDEN) Surface-Water Interpolation Model, Version 3
}

\author{
By Saira Haider, ${ }^{1}$ Eric Swain, ${ }^{1}$ James Beerens, ${ }^{1}$ Matthew Petkewich,, Bryan McCloskey, ${ }^{2}$ \\ and Heather Henkel ${ }^{1}$
}

\section{Abstract}

The Everglades Depth Estimation Network (EDEN) is an integrated network of water-level gages, interpolation models that estimate daily water-level data at ungaged locations, and applications that generate derived hydrologic data across the freshwater part of the Greater Everglades landscape. Version 3 (V3) of the EDEN interpolation surface-water model is the most recent update, replacing the version 2 (V2) model released in 2011.

The primary revision for the $\mathrm{V} 3$ model is the switch to the $\mathrm{R}$ programming language to create a more efficient and portable EDEN code relative to V2, without reliance on proprietary software. Using $\mathrm{R}$, the interpolation script runs over 10 times faster and is more easily updated, for example, to accommodate changes in the gage network or to incorporate $\mathrm{R}$ software updates. Additional revisions made for the V3 model include updates to the interpolation model, the gage network, and groundwater-level estimations. The EDEN model domain in the Greater Everglades and Big Cypress National Preserve is divided into subdomains that are based on hydrologic boundaries. In the V3 model, the number of subdomains was increased from five to eight, which allows hydrologic boundaries, such as levees and canals, to be better represented in the interpolation scheme. Five pseudogages were added to constrain the water-level surface at subdomain boundaries. Changes made to the water-level gage network between the implementation of the V2 and V3 models are incorporated, and groundwater-level estimations are added, which are important information for hydrologic and ecological studies.

Summary model performance statistics indicate similar accuracy in water-level surfaces generated by the V3 and V2 models, with a root mean square error of 4.78 centimeters for both interpolation models against independent water-level measurements. Providing stability and continuity for the EDEN user community, the V3 model closely replicates the V2 model, with a root mean square difference of 3.87 centimeters for interpolated surfaces from April 1, 2014,

\footnotetext{
1U.S. Geological Survey.
}

${ }^{2}$ Cherokee Nations Technologies, contractor to U.S. Geological Survey. to March 31, 2018. The additional groundwater levels provide a realistic estimate of the saturated groundwater surface continuous with the surface-water surface for Water Conservation Areas 2A and 2B from 2000 to 2011. This continuous surface is a more accurate estimation of the spatial distribution of water in the hydrologic system than before, providing needed information for ecological studies in areas where depth to water table affects habitats. Development of the EDEN V3 model advances the tools available to scientists and resource managers for guiding large-scale field operations, describing hydrologic changes, and supporting biological and ecological assessments.

\section{Introduction}

The Everglades Depth Estimation Network (EDEN) is a resource that integrates real-time water-level data from a network of gages with interpolation models and generates daily water-level surfaces and derived hydrologic data across the freshwater part of the Greater Everglades landscape and Big Cypress National Preserve (BCNP). Scientists, decisionmakers, and managers use EDEN to help monitor and assess Greater Everglades restoration and conduct research. The primary purpose of EDEN is to provide consistent, documented, and readily available hydrologic and ground-elevation data for the Everglades (Telis, 2006), and it includes additional datasets and tools, including rainfall and evapotranspiration data, hindcast datasets, benchmark data, ecological applications, statistical analyses, and data visualization tools (Patino and others, 2018).

The Greater Everglades, which encompasses the majority of the Florida peninsula south of Lake Okeechobee (fig. 1), has been greatly altered from its original state over the last century. It has been channelized, leveed, and drained to meet water-supply and flood-control requirements for the expanding urban and agricultural areas of southern Florida. Beginning in the 1990s, a concerted effort to restore the Everglades was initiated, leading to the Comprehensive Everglades Restoration Plan (CERP; U.S. Army Corps of Engineers, 1999). The 
objective of CERP is to recreate more natural conditions and restore the diverse and abundant flora and fauna of the previously undisturbed wetlands.

The REstoration COordination and VERification (RECOVER) program is a component of CERP that links science to decision making and uses scientific methods and monitoring to evaluate and assess CERP's performance, refine and improve CERP with new data, and ensure that an ecosystem-wide perspective is maintained throughout the restoration process (RECOVER Leadership Group, 2012). Since 2006, EDEN is one tool that RECOVER has supported collaboratively with the U.S. Geological Survey (USGS) Greater Everglades Priority Ecosystems Science Program.

Water levels in the water conservations areas (WCAs), Everglades National Park (ENP), and BCNP are reported daily, and the EDEN interpolation model generates a continuous water-level surface from this collected field data. While these interpolations of the water-level surface are one of the primary EDEN products, EDEN includes other data and applications commonly used by the Everglades restoration community. The Explore and View EDEN (EVE) application (https://sofia.usgs.gov/eden/eve/) allows users to view and download water-level, rainfall, and potential evapotranspiration data at EDEN gages in graphical or tabular formats. The EDEN Cape Sable Seaside Sparrow Viewer application (https://sofia.usgs.gov/eden/csss/) was developed to evaluate water depths and other important metrics in Ammospiza maritima mirabilis (Cape Sable seaside sparrow) habitats on a historical and real-time basis. The coastal salinity index indicates potential drought conditions and is based on statistics computed for salinity measured at coastal stations. This index can be viewed along with other real-time environmental parameters and statistics in the Coastal EDEN web application (https://sofia.usgs.gov/eden/coastal/). Water-level conditions across ENP, WCA 3A, and WCA 3B, along with potential inundation conditions at gages and tree islands in these areas, can be monitored on the Everglades Restoration Transition Plan water-level alert map (https://sofia.usgs.gov/eden/ertp/). The applications and maps are all accessible on the EDEN web page (https://sofia.usgs.gov/eden/).

The original version of the EDEN surface-water interpolation model, version 1 (V1), was developed by Pearlstine and others (2007). This was the first functional version to use radial-basis functions to interpolate continuous water-level surfaces from discrete field-site data. There were 249 stations included in the EDEN V1 model, and the geostatistical analysis tool in Esri's ArcGIS 9.1 (Esri, 2005) was used to implement the radial-basis function calculation. This method was continued in the version 2 (V2) model with Esri's ArcPy in ArcGIS 9.3 (Esri, 2008) and involved an expansion of the EDEN model domain to include an additional portion of southern BCNP and northwestern ENP upstream of the marsh and mangrove wetlands. To better define discontinuous waterlevel surfaces across levees and other hydrologic boundaries, the model domain was divided into five subareas to incorporate subdomain models (Telis and others, 2015). Changes in the water-level gage network were also incorporated in the V2 model, and a model-error analysis was performed using waterlevel data at elevation benchmarks.

Making the EDEN V2 interpolation model more efficient, accessible, and nonproprietary has been a priority. These issues have been addressed in the EDEN version 3 (V3) model because of advances in open-source software and web-compatible codes. The $\mathrm{R}$ programming language is a free and open-source software environment for statistical computing and graphics (Gentleman and Ihaka, 1997) that can perform the interpolations and other tasks required to produce EDEN water-level surfaces. Switching to the R programming platform improves the interpolation model workflow by (1) increasing processing speed, (2) simplifying updates to the model scripts to accommodate changes in the gage network, (3) decentralizing the computational platform, and (4) easing the process of ensuring compatibility with new versions of the programming software because of the transparency and backward compatibility of the R platform. The R-based V3 of the EDEN interpolation model is faster than the V2 model because of increased computational efficiency. The EDEN V3 model is more easily transferred between computational platforms because R, unlike ArcPy, can be easily installed on Mac OS and Linux, requires little overhead, does not require a paid license, and requires a minimal list of system requirements.

As was the case with the advancement from the V1 to V2 model, changes to the water-level gage network have occurred since the development of the V2 model and must be incorporated into the computation of the daily water-level surfaces. In addition, recent efforts to estimate groundwater levels when the wetland surface is dry have been implemented in response to the needs and requests of the ecological research community.

The advancements to the full set of EDEN tools since the implementation of V2 have improved its ability to provide consistent, documented, and readily available hydrologic and ground-elevation data for the Everglades. The V3 model is the latest EDEN development to support the hydrologic research and management community with the crucial data and analysis needed for Everglades restoration. The R package for the EDEN V3 interpolation model can be found online at https://code.usgs.gov/water/eden (Haider and McCloskey, 2020).

\section{Purpose and Scope}

The purpose of this report is to document the EDEN V3 model that estimates daily water-level surfaces for the freshwater part of the Greater Everglades and BCNP through interpolation of discrete water-level measurements (fig. 1); the report also summarizes model performance statistics. The differences between the V3 model and previous EDEN interpolation models are explained. The use of the R programming language to create more efficient and portable model code and the incorporation of additional groundwater-level representations are described, along with changes in the water-level gage network. 


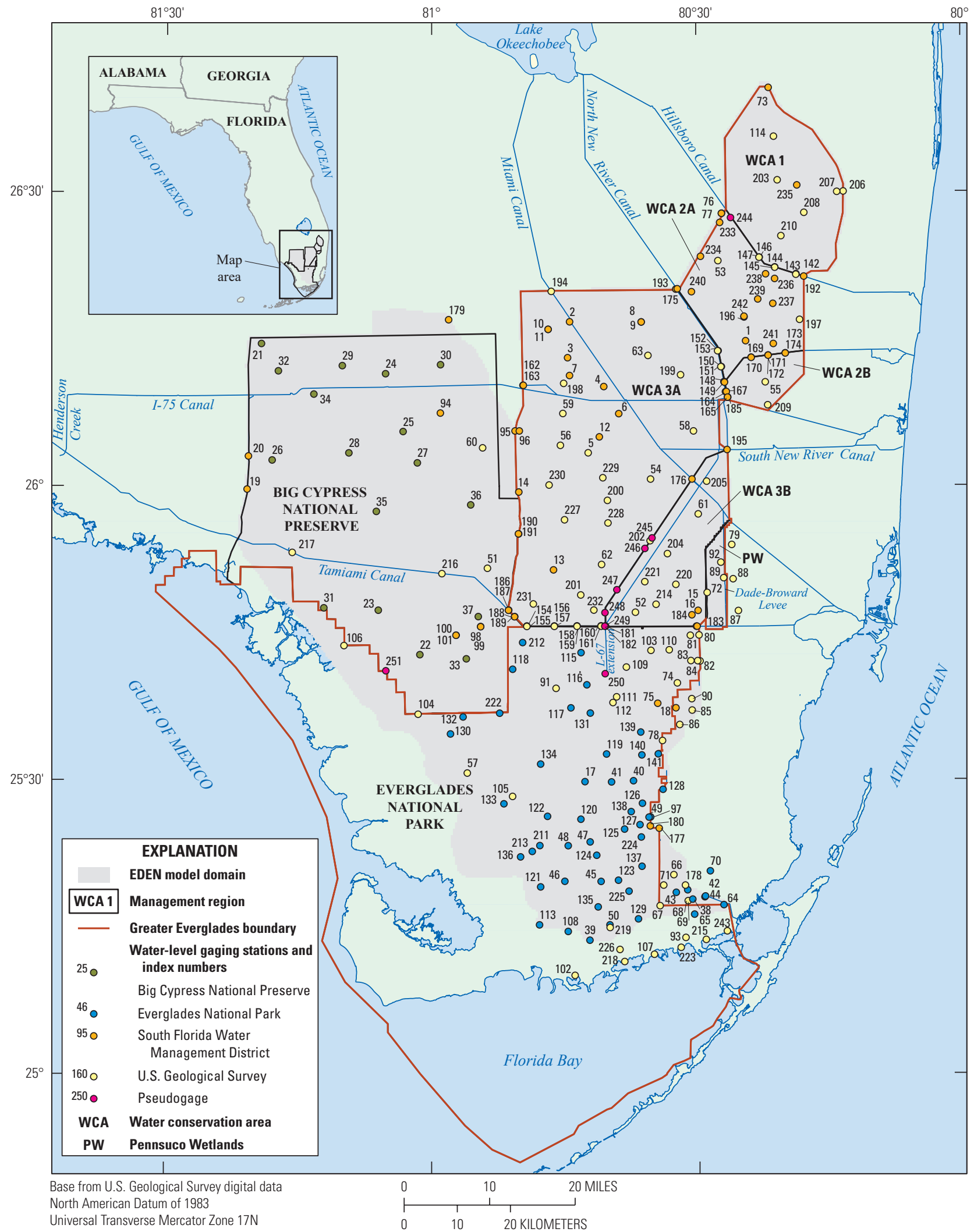

Figure 1. Everglades Depth Estimation Network (EDEN) model domain, management regions, and location of EDEN water-level gaging stations used in the EDEN surface-water model, version 3. Index numbers refer to gages listed in appendix 1 , which includes descriptive data and site information for each gage. 
An important part of the USGS mission is to provide scientific information for the effective management of the Nation's water resources. The EDEN V3 model is optimized to help researchers and resource managers better understand complex natural systems and, therefore, better manage the resources of these systems. The approach can readily be applied to other natural systems to support ecosystem restoration.

\section{Description of Study Area}

The study area includes parts of BCNP and ENP, all of WCAs 1, 2A, 2B, 3A, and 3B, and the Pennsuco Wetlands west of the Dade-Broward Levee (fig. 1). The EDEN V3 model domain includes a large part of the freshwater Everglades, which is a large wetland area overlying a broad platform of porous limestone that gently slopes from the southern end of Lake Okeechobee to Florida Bay. The land surface has a low gradient, with a slope averaging 1 inch per mile, and the main portion of the Everglades is a broad, swale-like channel that is 50 miles wide.

The predevelopment landscape of the Everglades was dominated by sawgrass plains in the northern region and by ridge and slough landscape in the central and southern regions (fig. 2; Davis, 1943). Beginning in the Kissimmee Valley, extending through Lake Okeechobee and ending at the southern end of the Florida peninsula, the predrainage Everglades were inundated by a slow flowing and shallow sheet of water for most of the year (fig. $3 A$ ). The landscape pattern of tree island ridges and interconnecting sloughs combined with the dynamic hydrologic processes, including water storage and sheetflow, created diverse vegetation communities and habitats for native flora and fauna (Fling and others, 2004).

The first Congressional action that initiated draining the Everglades was the Swamp Land Act of 1850, which authorized the transfer of 200 million acres of Federal land to the State of Florida for conversion to farmland. Canals were used to drain water from the wetlands quickly and directly to the ocean. In 1948, following a devastating hurricane, the Central and Southern Florida Project created a compartmentalized Everglades consisting of a regulated system of WCAs with adjacent nationally protected lands (fig. 3B). The WCAs (fig. 1), completed in the 1960s, serve to modulate variations in hydrologic patterns, help recharge the region's principal drinking-water aquifer, and protect against saltwater intrusion along the coast. Water levels in the WCAs and ENP are managed through water regulation schedules that dictate water levels within the WCAs on the basis of current conditions, time of year, and minimum flow requirements. Ongoing efforts to restore the Everglades to more historic conditions involve decompartmentalizing the WCAs and creating more continuous flowways.

ENP was dedicated in 1947 primarily to preserve the unique flora and fauna of the area and to protect the primitive, undeveloped natural conditions of the Everglades.
Encompassing about 2,200 square miles and consisting of freshwater sloughs, sawgrass marshes, wet prairies, pine and mangrove forests, and saline tidal flats, ENP has extremely low and flat topography with land-surface elevations ranging from 0 feet (ft) above the North American Vertical Datum of 1988 (NAVD 88) along the coastlines of Florida Bay and the Gulf of Mexico to $6 \mathrm{ft}$ above NAVD 88 in parts of the interior.

BCNP was established in 1974 to preserve the distinctive natural areas that drain into Florida's southwest coastal fisheries and to provide habitat for several endangered flora and fauna, including Felis concolor coryi (Florida panther). Although the BCNP receives some surface-water inflow from the north, it is primarily a rain-driven watershed that flows in a southwesterly direction to the coast of the Gulf of Mexico (Sobczak and others, 2011).

\section{Approach}

The EDEN interpolation model integrates discrete field-gage data into a continuous representation of the water-level surface. Radial basis functions (RBFs) calculate smooth surfaces from a large number of data points and produce accurate results for gently sloping surfaces, such as low-gradient land surfaces or water-level surfaces. If abrupt changes in water-level surfaces are present (ArcGIS Resources, 2013), such as those along canal boundaries at the margins of the WCAs, the technique is not appropriate. Palaseanu and Pearlstine (2008) developed the initial interpolation method for generating the EDEN daily waterlevel surfaces for the V1 model by using the RBF multiquadric method in subdomains. This method is retained in the V2 and V3 models and has proven reasonable and robust. Although the EDEN platform has been modified to rely on R code, we continue to use the RBF method so that continuity in methodology is maintained and because it continues to be the most appropriate interpolation method for the type of data and system.

The conversion of the EDEN surface-water interpolation model to the $\mathrm{R}$ programming platform has the following advantages: (1) updates are pushed to R regularly; (2) version tracking and distributed repositories can be used; (3) backward compatibility is generally maintained; (4) older versions of $\mathrm{R}$ and its statistical packages can be kept and used without security concerns (unlike Esri software); and (5) updates to R minimally change the RBF interpolation script, if at all. The $\mathrm{R}$ Core Team (2018) discloses and describes all updates to the base language in a fully transparent manner, and any changes to contributed packages such as geospt (which contains the RBF functionality) are similarly documented. In addition, $\mathrm{R}$ is an open-source environment, so the details of the RBF calculations used to create the water-surface interpolation are available to the public. This is not the case with the proprietary tools used in the EDEN V2 model. 

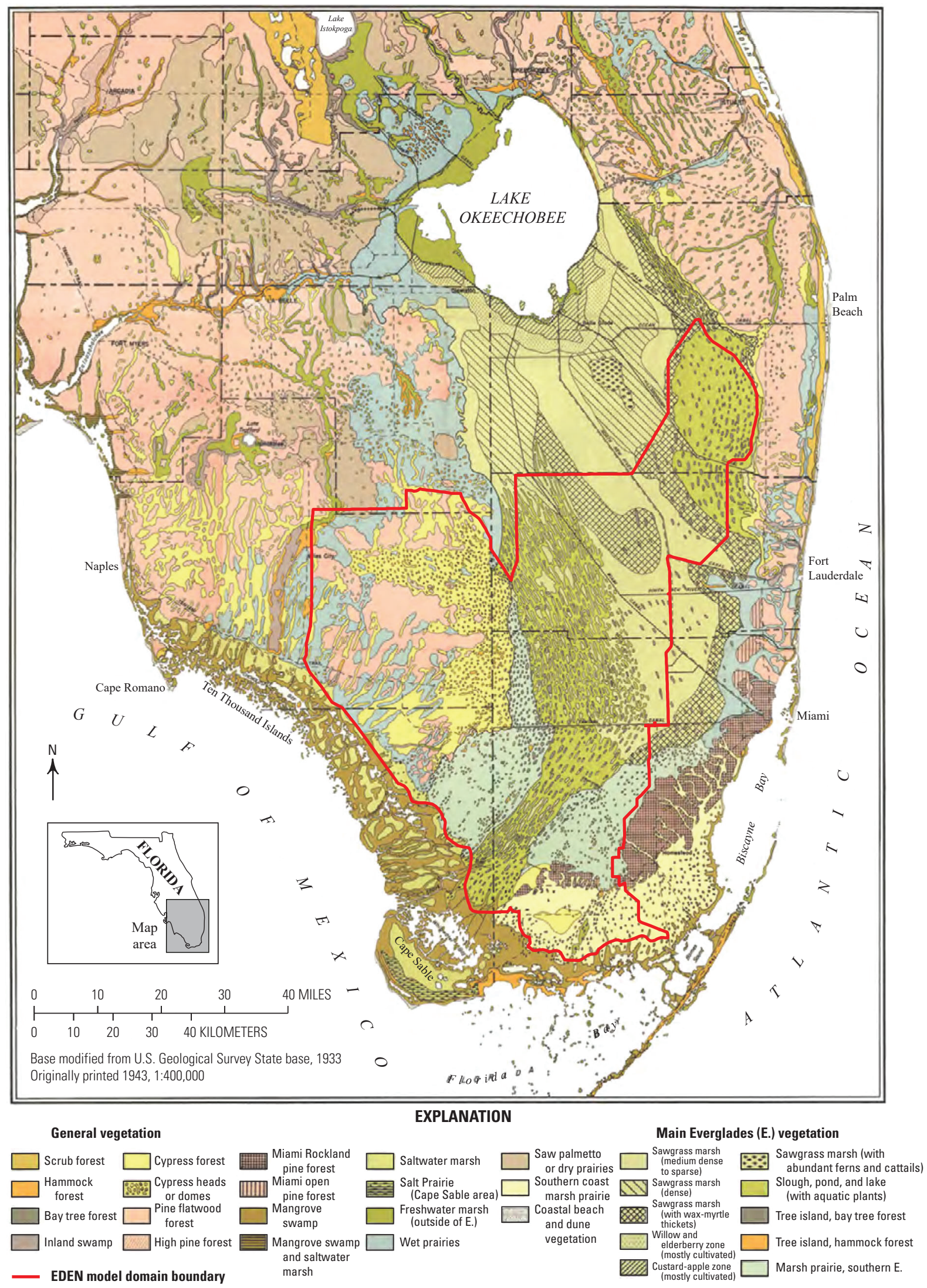

Figure 2. Vegetation of southern Florida circa 1943 (modified from Davis, 1943) and the Everglades Depth Estimation Network (EDEN) model domain. 
$\boldsymbol{A}$

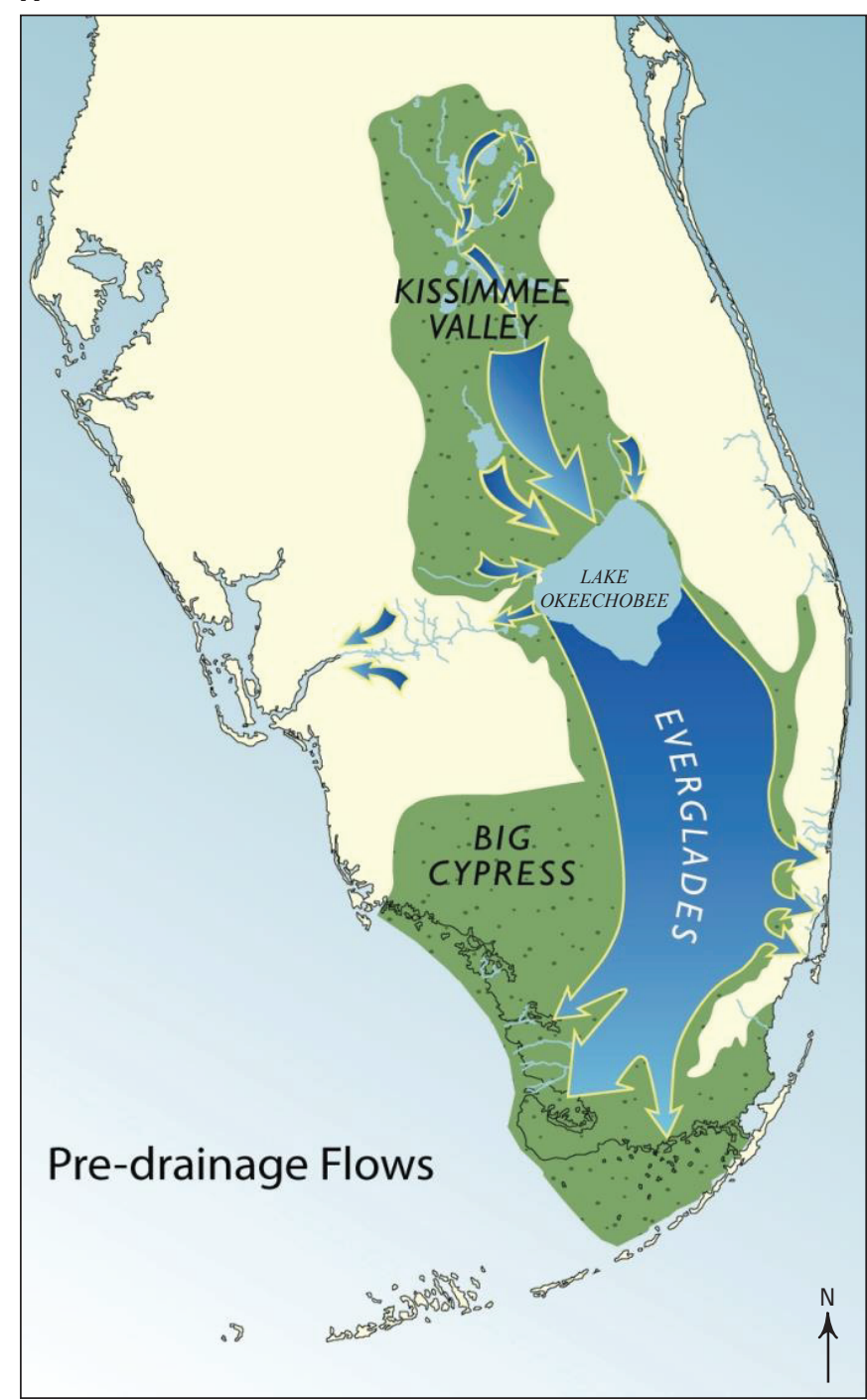

B

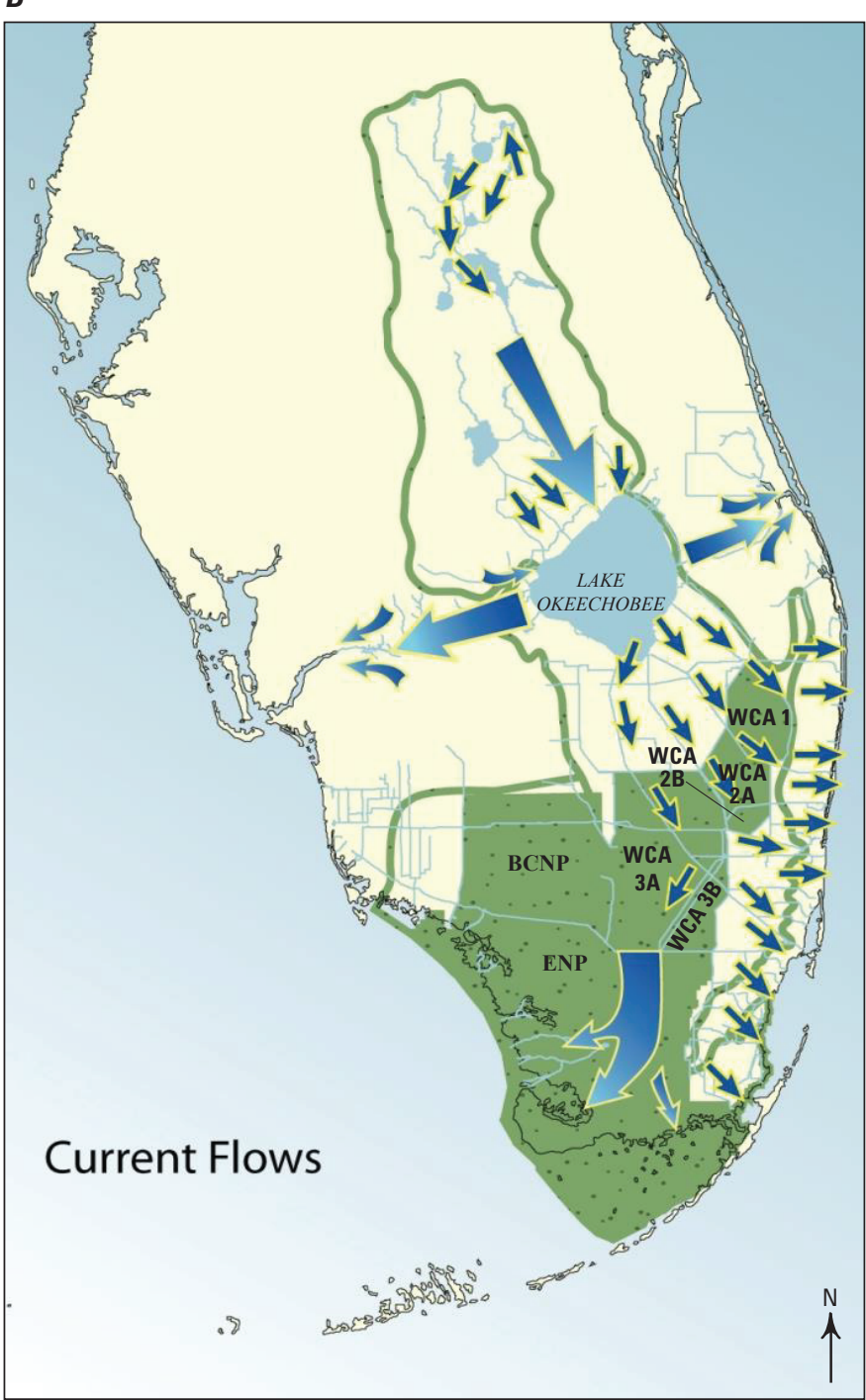

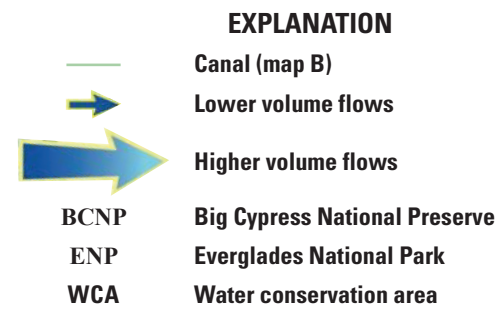

Figure 3. Maps of the Everglades showing flow directions, $A$, before drainage, $B$, after drainage and compartmentalization. Map images courtesy of the South Florida Water Management District.

Another major advantage of using the $\mathrm{R}$ language for the EDEN V3 interpolation model is that it performs more than 10 times faster than the interpolation in the V2 model. Interpolating a single quarter (about 90 days) with the $\mathrm{V} 2$ model on a dedicated server takes approximately 150 minutes, whereas the V3 model using the R platform takes approximately 12 minutes. Even on an ordinary desktop, the V3 model requires considerably less computational power and runs in approximately 25 minutes. In addition, the R scripts used to run the interpolation can be more easily revised to accommodate changes and updates in the gage network. In the V2 model, the names of older gages and decommissioned gages were explicitly hard coded into the scripts. Hard coded gage names were removed in the V3 model, and the new scripts will more easily incorporate any such changes automatically by being tied directly to the EDEN gage database, which accommodates such changes in real time. Finally, the R scripts used to run the V3 model can run on any machine that meets 
minimal requirements (for example, has $\mathrm{R}$ software and a network connection), allowing the model to be run in multiple locations and not be tied to individual users or servers.

Further, the R scripting environment allows for streamlining much of the EDEN workflow into a consolidated set of scripts that can be distributed widely to team members to complete these tasks on an as-needed basis. The workflow includes (1) retrieving and collating gage data from cooperator agencies and preparing data for review by USGS staff; (2) retrieving reviewed data, generating data flags, and uploading into the EDEN database; (3) preparing input data and running the EDEN V3 model; (4) packaging and posting the model data; and (5) generating and posting all related data products. Whereas before these tasks involved a large suite of software tools, much of it is now handled by the new R scripts.

As the RBF method is not appropriate for situations when high water-level gradients are present over short distances, the V3 model domain was divided into eight subdomains separated by water-level discontinuities caused by the major levee system that divides and controls the wetlands and conservation areas.

Development of the EDEN V3 interpolation model involved two substantial formulation changes made after the release of the V2 interpolation model:

1. New R scripts were added that access daily water-level data and output the interpolated water stage and depth.

2. Methods to estimate gage values were revised to increase the accuracy of groundwater values in the interpolation surface.

\section{Changes in Field Gages and Conditions}

Daily water-level surface data are reported in EDEN back to 1991 by means of gage data hindcasting with artificial neural networks (Conrads and Roehl, 2007). Over the years, new gages have been installed in the study area and some older gages have been removed. These changes have the potential to affect the computed water-level surface beyond those effects localized at the gage. For example, missing data from gages are estimated using data from selected highly correlated nearby gages (Conrads and Petkewich, 2009). If a gage is discontinued, it affects the record of other gages using it for estimating a missing record. A new gage added to the network might similarly change the way missing data for existing gages are estimated. These effects require reassignment of missing record gages whenever changes in the system occur. Interpolated stage surfaces are delivered quarterly to users via the EDEN website. To minimize confusion in maintaining a list of input gages to the model and to provide a level of consistency across calendar quarters, the standard practice is to estimate any newly added or removed gages forward or backward to the end of the relevant quarter so that a single set of input gages is used for the entirety of any surface produced quarterly. The EDEN database maintains a master list that specifies which gages are used each quarter within the period of record to document changes in the model and to allow for any surface recalculations in the future.

\section{Radial Basis Function Interpolation in the EDEN V3 Model}

The EDEN V3 model was developed in the R language (R Core Team, 2018) using the packages rgdal (Bivand and others, 2018), geoR (Ribeiro and Diggle, 2016), raster (Hijmans, 2017), and geospt (Melo and others, 2012) to interpolate the water surface. As of July 2019, 220 gages are used in the V3 model to run the RBF interpolation for the eight subdomains (figs. 1 and 4; appendix 1, table 1.1). We tested values for the RBF parameters to best estimate water surfaces and to try to maintain consistency with V2 model water surfaces, a priority for the user community (table 1).

The RBF anisotropic parameters and associated values in the V3 model are an angle of $350^{\circ}$ and an ellipsoid axes ratio of $31 / 30$. The $\mathrm{V} 3$ model specifies eight nearest neighbor gages to be drawn from the search neighborhood, and they can be in any direction from a given gage but must be within the same subdomain. The only exception is in the Pennsuco Wetlands (hereafter, "PW") subdomain, which contains fewer than eight gages; it is programmed to use as many gages as are available. To account for the flow boundaries caused by canals and levees, V3 interpolates water surfaces separately for the eight subdomains, the borders of which are determined by the locations of water control features (as canals) that impede flow (fig. 3B). The eight subdomains are WCA1, WCA2A, WCA2B, WCA3A, WCA3B, PW, a combined subdomain that includes BCNP and ENP (hereafter referred to as "NPS"), and a subdomain called "L67ext," which is the region south of WCA3B and east of the L67 canal extension (figs. 1, 4, and 5). The L67ext is a special case, because the canal's influence on the water surface decreases with decreasing latitude. The difference in water-level surface between the NPS and L67ext subdomains decreases toward the south (fig. 5), and the V3 model estimates this change by using southern gages along either side of the L67 canal extension for both the NPS and L67ext subdomains, but not northern gages. This method works well to match the subdomain surfaces at the southern border of the L67 canal extension, and no bias adjustment is used to match the two subdomains.

Differences in the V3 model relative to the V2 model are small but include using a different approach for the search neighborhood, with absolute nearest neighbors rather than an 8-sector search neighborhood. The methodology was changed, because the RBF in the geospt R package does not contain functionality for multisectored search neighborhoods. Additionally, the V2 model has five subdomains instead of eight. Further details can be found in the EDEN V2 model report (Telis and others, 2015). 


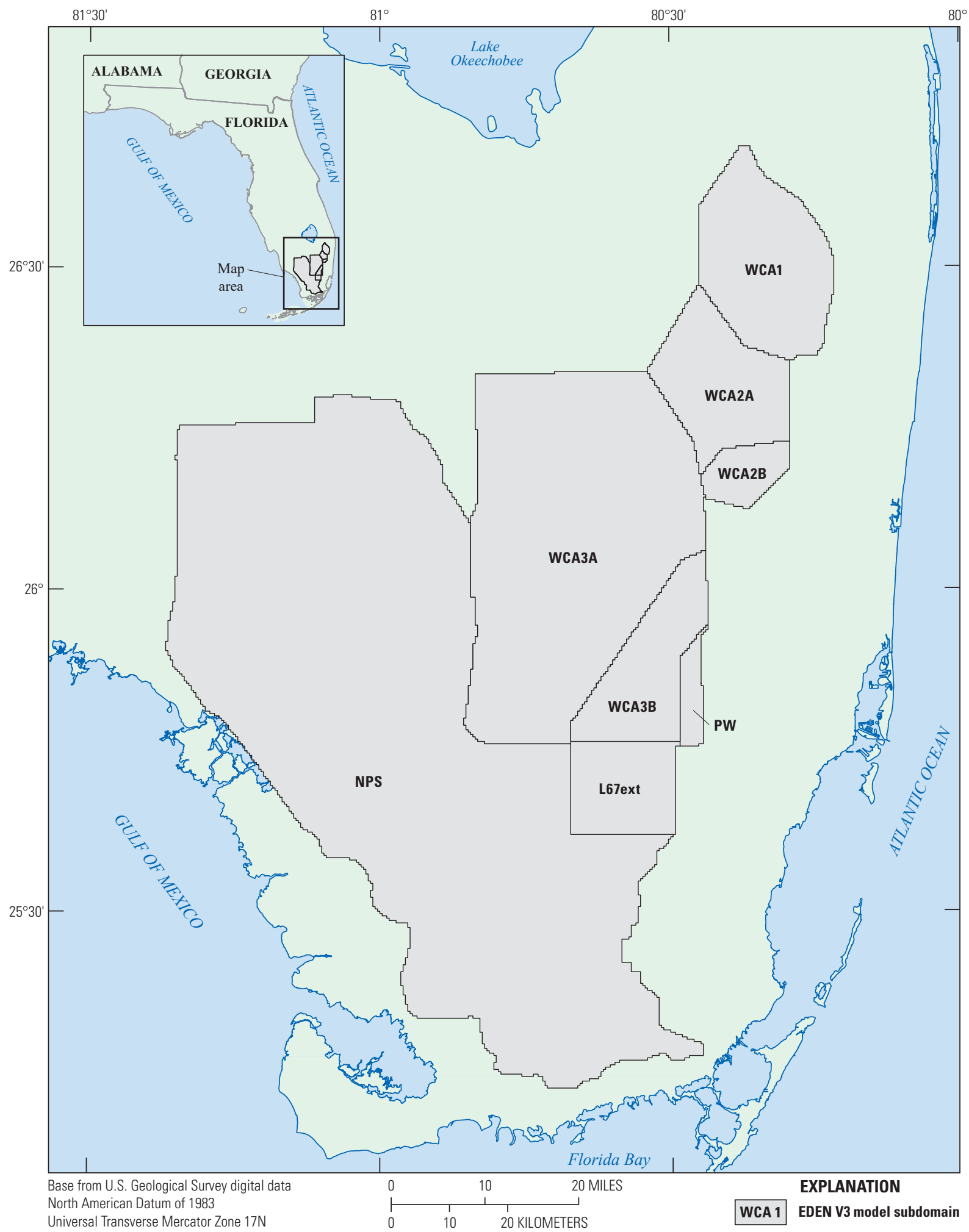

Figure 4. Eight subdomains used in the Everglades Depth Estimation Network (EDEN) version 3 model. 
Table 1. Radial basis function (RBF) parameter values for the Everglades Depth Estimation Network (EDEN) version 3 (V3) and version 2 (V2) models.

\begin{tabular}{lcc}
\hline \multicolumn{1}{c}{ RBF parameters } & V2 model & V3 model \\
\hline Kernel function & Multiquadric & Multiquadric \\
Kernel parameter(s) & 16.77 & 0 \\
Maximum neighbors & 1 & 8 \\
Minimum neighbors & 11 & 18 \\
Sector type & 8 sector & Not applicable \\
Angle & $350^{\circ}$ & $350^{\circ}$ \\
Major semiaxis & 31,000 & 31 (uses ratio only) \\
Minor semiaxis & 30,000 & 30 (uses ratio only) \\
\hline
\end{tabular}

${ }^{1}$ Except in the case of the Pennsuco Wetlands subdomain, which contains fewer than eight gages. In this case, the interpolation uses as many gages as are available.

Three pseudogages (index numbers 249-251) were retained from the V2 model, all of which are used in the NPS surface interpolation. One pseudogage uses the value of gage S12D_T (index number 161), and the other two each use an average of two nearby gages (NP202 and NESRS1, index numbers 116 and 109, respectively; BCA19 and MO-214, index numbers 31 and 104, respectively); the former of these two averages is also used in the L67ext subdomain. For the V3 model, five additional pseudogages were created on subdomain borders. These pseudogages act to constrain the water surface in areas where levees and canals impede surface flow. The locations were selected during the V3 model development stage to maintain consistency with surfaces from the V2 model (fig. 1). One pseudogage is located on the border between WCA1 and WCA2A (index number 244, fig. 1) and has the same water stage value as gage S10D_T (index number 147). Four pseudogages are located on the border between WCA3A and WCA3B (index numbers 245-248). The water stage values for these pseudogages were calculated from a linear interpolation of the values for gages $\mathrm{S} 151{ }_{-} \mathrm{H}$ and S333_H (index numbers 176 and 181, respectively).

To determine the kernel parameters for the RBF in the V3 model, we used the geospt function graph.rbf() to find the optimal parameter values by minimizing the root mean square prediction error. The graph.rbf() function returned a value of 0 as the optimal value for both kernel parameters, eta (the smoothing parameter) and rho (the robustness parameter). We also wanted to determine which parameters' values would result in surfaces similar to those produced by the V2 model, so about 150 simulations were run, testing combinations of the two geospt RBF parameters over ranges from 0 to 50 . Experimentation demonstrated a positive relation between kernel parameter values and the amount of deviation from the V2 model surfaces.

\section{Representation of Groundwater Levels}

Most EDEN gages are surface-water sites (table 1.1) that contain a stilling well equipped with a float and shaft encoder to measure water-level data. During the dry season, the float may settle on mud or peat when the water level drops below land surface. EDEN also includes groundwater wells that allow water-level measurement below land surface. The number of groundwater sites in EDEN is relatively small compared to the total number of sites in the network, and the groundwater sites are generally confined to the L67ext and PW subdomains. Some of the surface-water gages are constructed in topographic depressions so that they can measure water levels lower than the average land surface surrounding the gage, but all gages have a minimum stage that can be measured, which is the bottom of the well. The number of gages available to measure dry-season conditions decreases substantially as the water level in an area drops near or below land surface. Groundwater levels, however, are relevant to several biological assessment techniques, and EDEN water-level data are an essential part of such research (U.S. Fish and Wildlife Service, 2010; Sokol and others, 2013; Beerens and others, 2016; Botson and others, 2016).

With the V2 model, a method was developed for estimating groundwater surfaces starting with the dry season in 2012. These groundwater estimation methods are briefly described here but are provided in more detail in V2 model documentation (Conrads and Petkewich, 2009; Petkewich and Conrads, 2013; Telis and others, 2015; Petkewich and others, 2016). For surfaces generated before 2012, the V2 model represented water-level surfaces when the surface was wet but represented gage minimum measurement levels when the surface was dry. When data for a gage were missing or flat (that is, at a constant value near the land-surface elevation or when the water level dropped below the water-level sensor), the estimated water level at that gage was set to $0.01 \mathrm{ft}$ below the last measured value. Starting with the 2012 surfaces, the V2 model performed an analysis to represent dry-season groundwater conditions. For the V3 model, we have extended this time period back to 2000 and calculated groundwater dry-season estimates for water-level gages from 2000 to 2011 for WCA2A and WCA2B by replicating the $\mathrm{V} 2$ methods used to estimate groundwater from 2012 to the present. This new representation has been applied only to these two regions, and an expanded analysis covering the full EDEN model domain would be useful. 


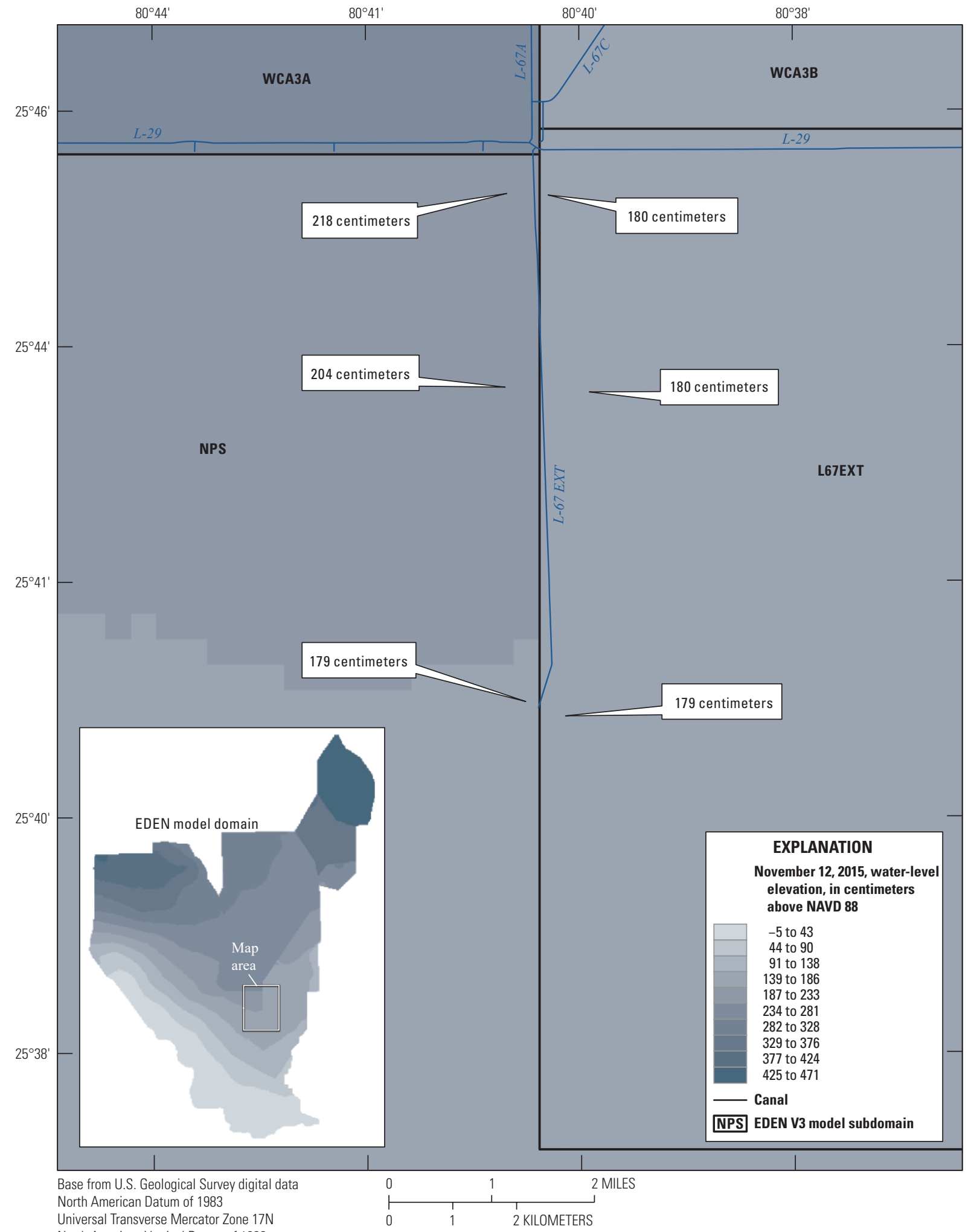

Figure 5. Map of the border between NPS and L67ext subdomains showing decreasing influence of the L67 canal extension with decreasing latitude. Example water-level surface is shown for November 12, 2015. Callout boxes indicate the water level of Everglades Depth Estimation Network (EDEN) cells located on either side of the canal. 
To estimate groundwater levels during the dry season, data from wells previously not used in the EDEN period of record from 2000 to 2011 were retrieved from USGS and South Florida Water Management District agency databases. For gages with missing or flat records, groundwater was estimated using nearby wells or gages that have water-level recording equipment located in topographic depressions. A correlation analysis was performed to determine the highest correlated five sites for each gage of interest. This search was initially confined to sites within the same compartmentalized region (for example, WCA3A, PW); however, if the number of gages was inadequate, the subdomain requirement was not enforced. The correlation analysis used all years in the full period of record for all sites but restricted the data to March, April, and May of each year. Correlations from the late dry season provided a selection of gages that best matched the dry-season recession observed for the gage of interest. Once the five best correlated sites were determined, simple linear regression models were developed to estimate groundwater for gages that went dry during the dry season (Petkewich and others, 2016). The only difference in methodology between the V3 and V2 models is the restriction of only using late dry-season months in the correlation analysis.

After surfaces with groundwater levels for 2000-2011 were developed for WCA2A and WCA2B, we evaluated the estimates to ensure that the resultant hydraulic gradients were appropriate. The development of this groundwater-level estimation scheme for each gage is an extensive process, but it would be useful to apply this process to the whole EDEN footprint.

\section{Results}

The EDEN V3 surface-water interpolations, such as the one shown in figure 6, have been released on the EDEN website since the third quarter of 2019. Daily production of water-level and depth maps continues, and the data are available for ecological applications and studies.

\section{Accuracy Assessment of EDEN V3 Model and Comparison to V2}

For validation and accuracy assessment of the V3 model surfaces, we used a set of independently collected field data measurements. As a comparison, we used this same independent data to assess the V2 model results. For a second assessment of V3 surfaces, interpolated surfaces were compared to measure consistency between V2 and V3 water-level surfaces. We desired continuity between the V2 and $\mathrm{V} 3$ interpolated water levels to allow researchers to use the V3 model surfaces without concern that earlier results would need modification.

\section{Validation for Accuracy Assessment With Benchmarks (Field Data)}

A set of 284 independent field data measurements were used to validate the V3 model results. These are the same independent data used to validate the V2 model (Telis and others, 2015). These data were collected from April 2007 to September 2011 throughout the EDEN model domain but are primarily from WCA3A. All measurements were referenced from the 31 Florida Department of Environmental Protection and 38 U.S. Army Corps of Engineers elevation benchmarks (fig. 7; Telis and others, 2015). We found the difference between the measured stage and the interpolated stage (for both V3 and V2) for each field measurement and calculated the root mean square error (RMSE) and standard deviation (SD) over all 284 points. The interpolated values from the V3 and V2 models show strong agreement with the measured values, with an RMSE of 4.78 centimeters $(\mathrm{cm})$ $(\mathrm{SD}=4.74 \mathrm{~cm})$ for the $\mathrm{V} 3$ model and $4.78 \mathrm{~cm}(\mathrm{SD}=4.77 \mathrm{~cm})$ for the V2 model. The similarity in RMSE between the two models demonstrates that the accuracy remains constant in the transition from the V2 to the V3 model.

\section{Consistency Between EDEN V3 and V2 Models}

For EDEN users concerned about differences between the V2 and V3 models, the consistency between the V3 and V2 model-derived surfaces was evaluated by comparing the magnitude and spatial distribution of differences from April 1, 2014, to March 31, 2018 (1,461 days). This analysis is not an accuracy assessment of model performance, but it provides the EDEN user community with an understanding of the differences between the V2 and V3 modes. The daily root mean square difference (RMSD) for the entire surface (resulting in one value per day) and the mean and SD of the daily RMSD for all 1,461 days were calculated. The evaluation shows that the mean RMSD between the V3 and V2 model-derived surfaces is $3.87 \mathrm{~cm}$ (fig. 8) with a SD of $0.67 \mathrm{~cm}$ (fig. 9).

Areas with the greatest RMSD between versions are mainly limited to Pennsuco Wetlands, along canals, and along the edges of the EDEN model domain, particularly the northern edge of BCNP and the southwestern edge of ENP (fig. 8). Areas with high standard deviation were more limited in extent and include the eastern edge of WCA2B, the northern area of $\mathrm{PW}$, the northwestern area of WCA3A, the northeastern area of BCNP, the southwestern area of WCA3B, and a couple of areas along the southwestern edge of the EDEN model domain (fig. 9). Overall, the V3 model shows high consistency with surfaces from the V2 model, providing stability for the user community. 


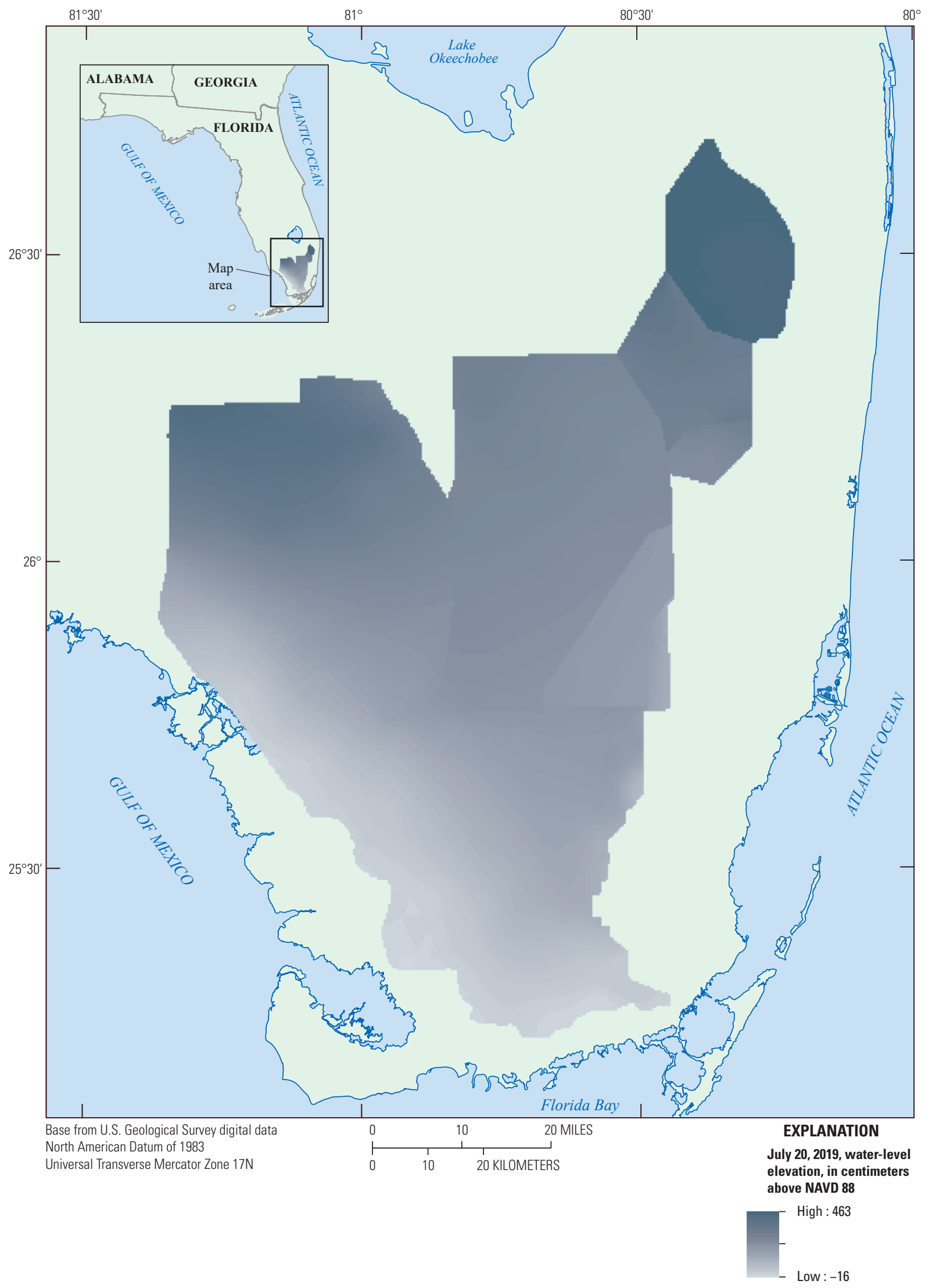

Figure 6. Water-level surface on July 20, 2019, from the Everglades Depth Estimation Network (EDEN) surface-water interpolation model, version 3 (V3). 


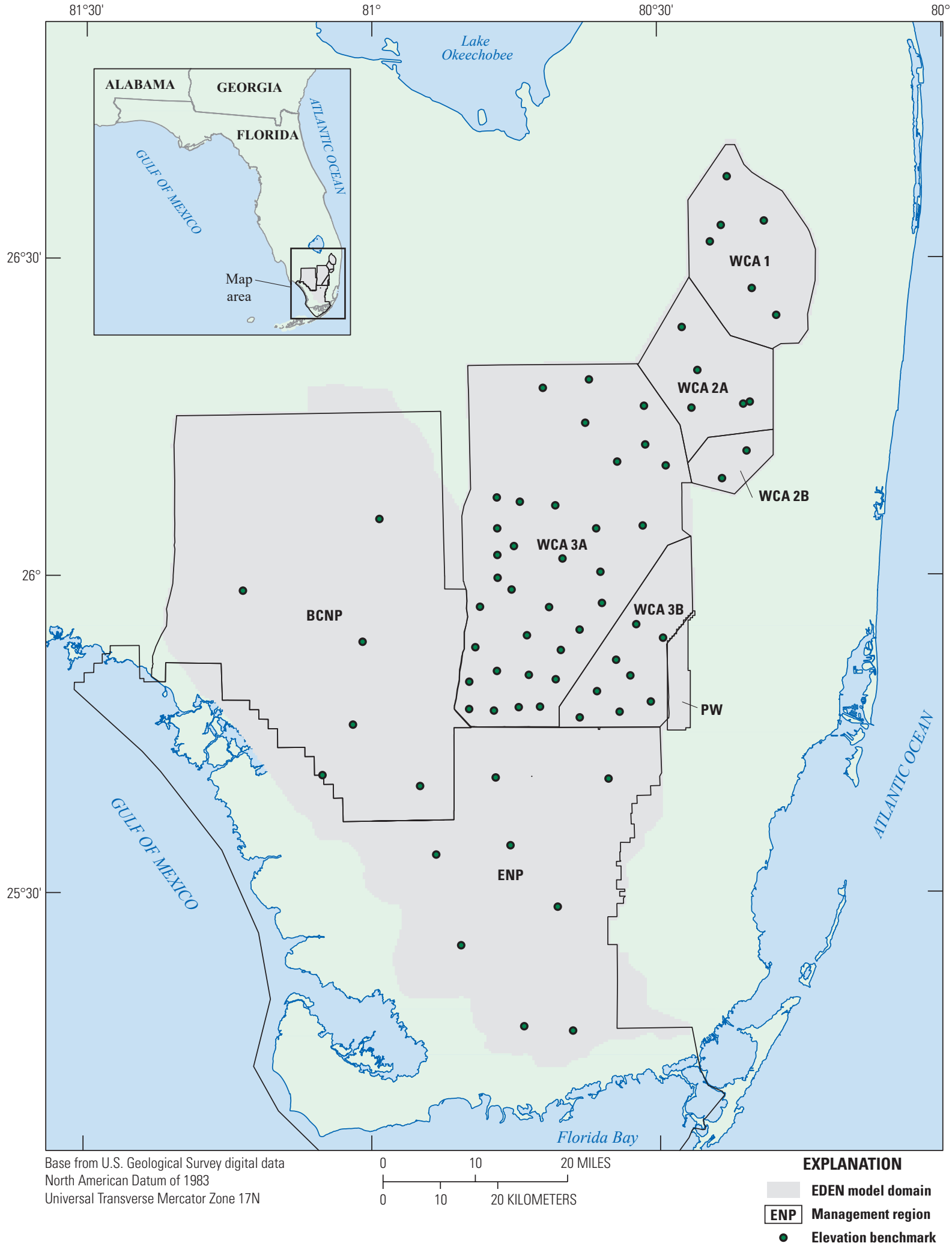

Figure 7. Locations of the Florida Department of Environmental Protection and U.S. Army Corps of Engineers elevation benchmarks in the Everglades Depth Estimation Network (EDEN) model domain. 


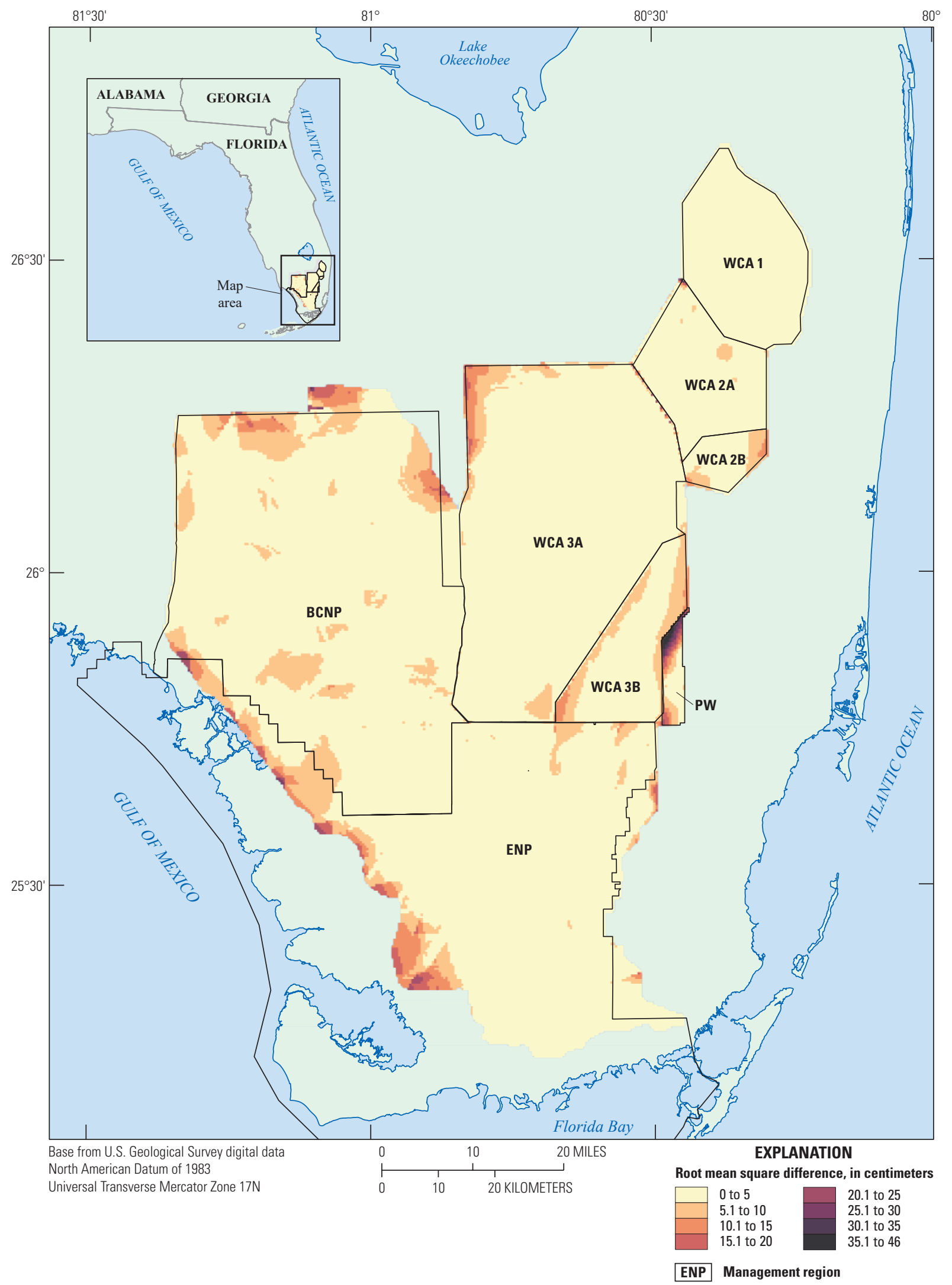

Figure 8. Root mean square difference (in centimeters) between water surfaces interpolated by the Everglades Depth Estimation Network (EDEN) version 2 (V2) and version 3 (V3) models, from April 1, 2014, to March 31, 2018. 


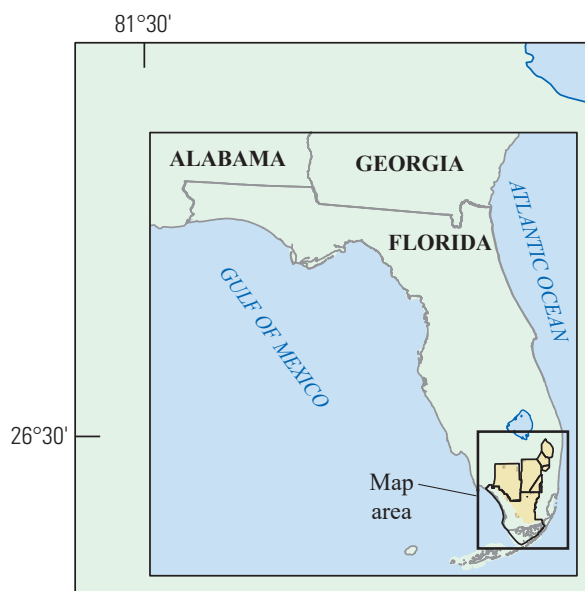

$81^{\circ}$

$80^{\circ} 30^{\prime}$

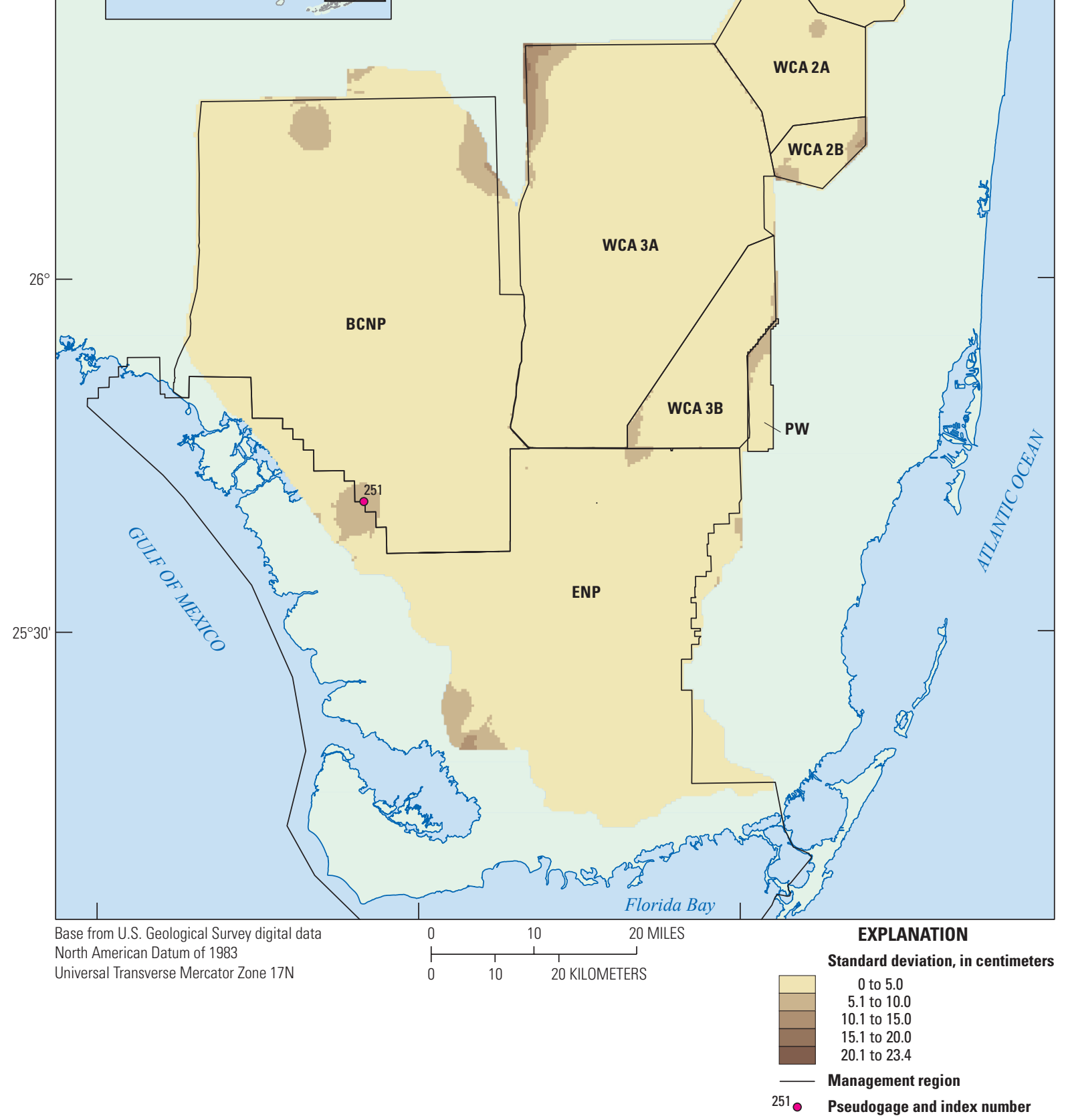

Figure 9. Standard deviation (in centimeters) between water surfaces interpolated by the Everglades Depth Estimation Network (EDEN) version 2 (V2) and version 3 (V3) models, from April 1, 2014, to March 31, 2018. 


\section{Considerations in Comparison of V3 and V2}

Updates and changes to gages can make the direct comparison between V3 and V2 surfaces less exact than it would be otherwise. Two of the gages located in ENP underwent name changes, from LO1 to MO-214 (index number 104, fig. 1) and from NE1 to NESRS1 (index number 109), but the older gage names were hard coded in the V2 model. Consequently, the gages were left out of the calculation for the values of two pseudogages located in ENP, pBCA19_MO214 and pNP202_NESRS1 (index numbers 251 and 250, respectively), and larger differences exist between the V3 and V2 surfaces in those areas. When developing the V 3 model, the script was updated to include those gages again, which caused a larger standard deviation around pBCA19_MO214 (index number 252) (fig. 9). These differences do not indicate an error in the V3 model interpolation but instead a correction and update of the interpolation script.

\section{Representing Groundwater Levels}

The representation of groundwater levels allows for a spatially continuous computation of the water surface, unlike the case in which all heads below land surface are omitted.
For WCA2A and WCA2B from 2000 to 2011 , the V2 model represented land surface in higher elevation areas during dry periods, but the V3 model represents the complete waterlevel surface (fig. 10). Without the groundwater estimates, when gages bottom out (that is, the water level drops below the minimum gage measurement), the interpolation creates mounding effects in the water surface (fig. 10A). These effects are caused by the gages erroneously indicating higher water levels (from bottoming out) than surrounding gages that are able to accurately measure water level. With the addition of groundwater estimates, mounding effects in the interpolated surface no longer exist (fig. 10B).

With the groundwater levels now being incorporated in the analysis, beginning in 2000, the V3 model surfaces for WCA2A and WCA2B can be used for gradient determination from 2000 to present. In combination with land-surface elevation data, the depth to water table can be determined, which is an important parameter in ecological studies that use the EDEN surface-water model to evaluate Everglades habitats (U.S. Fish and Wildlife Service, 2010; Sokol and others, 2013; Beerens and others, 2016; Botson and others, 2016). Extending the use of 2000-2011 groundwater levels through the entire study area would be a useful analysis for the EDEN user community. 


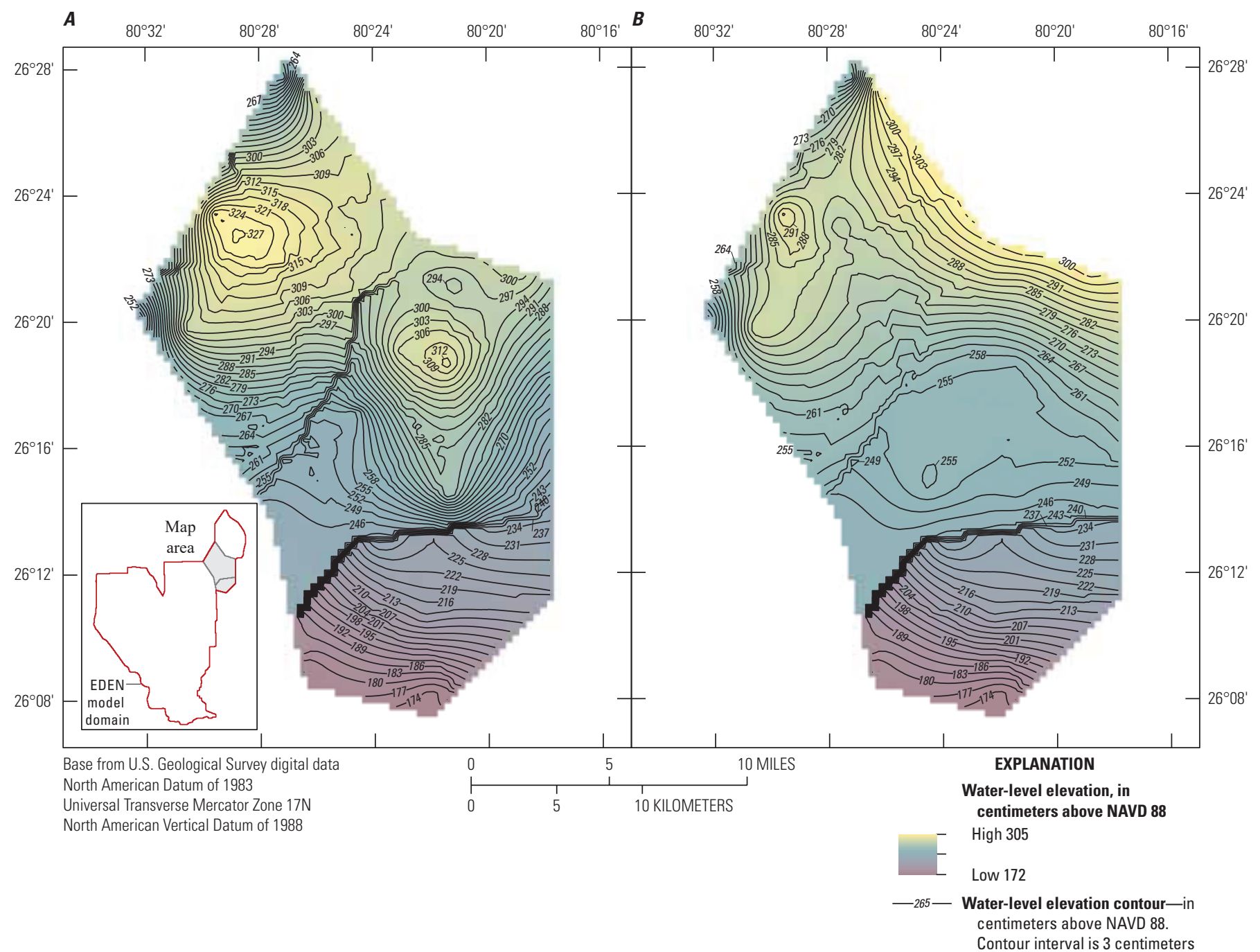

Figure 10. Comparison of water levels in Water Conservation Areas $2 A$ and $2 B$ on May 15, 2009, using the Everglades Depth Estimation Network (EDEN) version 3 (V3) model. $A$, The V3 surface without the additional groundwater estimates shows mounding, whereas, $B$, the V3 surface with groundwater estimates does not. 


\section{Summary and Conclusions}

The Everglades Depth Estimation Network (EDEN) model version 3 (V3) interpolates daily water-level surfaces for the freshwater part of the Greater Everglades and Big Cypress National Preserve and contains several updates and improvements not available in version 2 (V2). The primary update is the use of the $\mathrm{R}$ programming language to create a model that, compared to the previous version, is more than 10 times faster and more easily portable to a wider variety of computational platforms, without reliance on proprietary algorithms and software. The use of R software, which is free and open source, will make it easier and faster to update the V3 model script when changes occur in the gage network. Updates to R software are normally backward compatible, fully documented, and transparent, thus easing the process of keeping the V3 model script updated. Internal to the interpolation model, the number of subdomains has been changed from five to eight, which allows hydrologic boundaries such as levees and canals to be integrated into the interpolation scheme. Changes that occurred in the water-level gage network between the construction of the V2 and V3 models are accounted for and groundwater-level estimates are incorporated as important information for hydrologic and ecological studies. The R package for the EDEN V3 interpolation model is publicly available online at https://code.usgs.gov/water/eden.

Summary model performance statistics indicate similar accuracy in water-level surfaces between the V3 and V2 models, with a root mean square error of 4.78 centimeters for both models compared to independent water-level measurements. The objective of keeping the V3 model as close to V2 as possible was achieved, with a mean root mean square difference of 3.87 centimeters in water surfaces from April 1, 2014, to March 31, 2018, ensuring continuity and stability for the EDEN user community. The representation of groundwater levels in Water Conservation Areas 2A and 2B for the period from 2000 to 2011 is an important advancement and provides needed information for ecological studies where depth to water affects habitats.

The advancements in the V3 model allow EDEN to continue providing datasets to scientists and resource managers needed to guide large-scale field operations, describe hydrologic changes, and support biological and ecological assessments. The implementation of Everglades restoration will require the continued supply of this information to make informed decisions for the future of the Everglades ecosystem and South Florida as a whole.

\section{References Cited}

ArcGIS Resources, 2013, ArcGIS help 10.1: Accessed September 18, 2014, at http://resources.arcgis.com/en/help/ main/10.1/.

Beerens, J.M., Romañach, S.S., and McKelvy, M., 2016, Evaluating water management scenarios to support habitat management for the Cape Sable seaside sparrow: U.S. Geological Survey Open-File Report 2016-1107, 62 p., accessed October 2018 at https://doi.org/10.3133/ ofr20161107.

Bivand, R., Keitt, T., and Rowlingson, B., 2018, rgdalBindings for the 'geospatial' data abstraction library: R package version 1.3-2, accessed June 2018 at https://CRAN.R-project.org/package=rgdal.

Botson, B.A., Gawlik, D.E., and Trexler, J.C., 2016, Mechanisms that generate resource pulses in a fluctuating wetland: PLoS One, v. 11, no. 7, p. e0158864, accessed October 2018. https://doi.org/10.1371/ journal.pone.0158864.

Conrads, P.A., and Petkewich, M.D., 2009, Estimation of missing water-level data for the Everglades Depth Estimation Network (EDEN): U.S. Geological Survey Open-File Report 2009-1102, 53 p, accessed October 2018 at https://pubs.er.usgs.gov/publication/ofr20091120.

Conrads, P.A., and Roehl, E.A., Jr., 2007, Hydrologic record extension of water-level data in the Everglades Depth Estimation Network (EDEN) using artificial neural network models, 2000-2006: U.S. Geological Survey OpenFile Report 2007-1350, 56 p., accessed October 2018 at https://doi.org/10.3133/ofr20071350.

Davis, J.H., Jr., 1943, The natural features of southern Florida, especially the vegetation of the Everglades: Florida Geological Survey Bulletin, v. 25, p. 1-311.

Esri, 2005, ArcGIS desktop, release 9.1: Redlands, Calif., Environmental Systems Research Institute.

Esri, 2008, ArcGIS desktop. release 9.3: Redlands, Calif., Environmental Systems Research Institute.

Fling, H.E., Aumen, N.G., Armentano, T., and Mazzotti, F.J., 2004, The role of flow in the Everglades landscape: Gainesville, Fla., University of Florida, Institute of Food and Agriculture, CIR 1452, 11 p., accessed October 2018 at https://edis.ifas.ufl.edu/uw199. 
Gentleman, R., and Ihaka, R., 1997, The R language, in Billard, L. and Fisher, N., eds., Proceedings of the 28th Symposium on the Interface: The Interface Foundation of North America.

Haider, S., and McCloskey, B., 2020, EDEN: Everglades Depth Estimation Network water level and depth surfaces: U.S. Geological Survey software release, https://doi.org/ 10.5066/P9UCHYVB.

Hijmans, R.J., 2017, raster-Geographic data analysis and modeling: $\mathrm{R}$ package version 2.6-7, accessed September 2018 at https://CRAN.R-project.org/ package $=$ raster.

Melo, C., Santacruz, A., and Melo, O., 2012, geospt-An $\mathrm{R}$ package for spatial statistics: $\mathrm{R}$ package version $1.0-0$, accessed October 2018 at https://cran.r-project.org/web/ packages/geospt/index.html.

Palaseanu, M., and Pearlstine, L., 2008, Estimation of water surface elevations for the Everglades, Florida: Computers \& Geosciences, v. 34, no. 7, p. 815-826, accessed October 2018 at https://doi.org/10.1016/ j.cageo.2007.08.004.

Patino, E., Conrads, P., Swain, E., and Beerens, J., 2018. Everglades Depth Estimation Network (EDEN) - A decade of serving hydrologic information to scientists and resource managers (ver. 1.1, January 2018): U.S. Geological Survey Fact Sheet 2017-3069, 6 p., accessed October 2018 at https://doi.org/10.3133/fs20173069.

Pearlstine, L.G., Higer, A.L., Palaseanu, M., Fujisaki, I., and Mazzotti, F.J., 2007, Spatially continuous interpolation of water stage and water depths using the Everglades Depth Estimation Network (EDEN): Gainesville, Fla., University of Florida, Institute of Food and Agriculture, CIR 1521, 18 p., 2 apps, accessed October 2018 at https://edis.ifas.ufl.edu/uw278.

Petkewich, M.D., and Conrads, P.A., 2013, Estimation of missing water-level data for the Everglades Depth Estimation Network (EDEN), 2013 update: U.S. Geological Survey Open-File Report 2013-1251, 45 p, accessed October 2018 at https://pubs.usgs.gov/of/2013/1251/.

Petkewich, M.D., Daamen, R.C., Roehl, E.A., and Conrads, P.A., 2016, Using inferential sensors for quality control of Everglades Depth Estimation Network water-level data: U.S. Geological Survey Scientific Investigations Report 2016-5094, 25 p., accessed October 2018 at https://doi.org/10.3133/sir20165094.
R Core Team, 2018, R-A language and environment for statistical computing: Vienna, Austria, R Foundation for Statistical Computing, accessed October 2018 at https://www.R-project.org/.

RECOVER Leadership Group, 2012, RECOVERREstoration, COordination, and VERification: Comprehensive Restoration Plan Fact Sheet, 4 p.

Ribeiro, P.J., and Diggle, P.J., 2016, geoR-Analysis of geostatistical data: R package version 1.7-5.2., accessed October 2018 at https://CRAN.R-project.org/ package $=$ geoR .

Sobczak, R.V., Murphy, P.C., Clark, C.J., and Clark, R.E., 2011, Hydrologic and water quality monitoring partnership twenty-year anniversary report, winter 2011: National Park Service, U.S. Department of Interior, and Big Cypress National Preserve, Florida, 104 p., 3 apps.

Sokol, E.R., Hoch, J.M., Gaiser, E.E., and Trexler, J.C., 2013, Metacommunity structure along resource and disturbance gradients in Everglades wetlands: Wetlands, v. 34, p. 135-146, accessed October 2018 at https://doi.org/ 10.1007/s13157-013-0413-1.

Telis, P.A., 2006, The Everglades Depth Estimation Network (EDEN) for support of ecological and biological assessments: U.S. Geological Survey Fact Sheet 2006-3087, 4 p., accessed October 2018 at https://doi.org/10.3133/ fs 20063087 .

Telis, P.A., Xie, Z., Liu, Z., Li, Y., and Conrads, P.A., 2015, The Everglades Depth Estimation Network (EDEN) surface-water model, version 2: U.S. Geological Survey Scientific Investigations Report 2014-5209, 42 p., accessed October 2018 at https://doi.org/10.3133/sir20145209.

U.S. Army Corps of Engineers, 1999, Central and Southern Florida Project comprehensive review study: Jacksonville, Fla., Final integrated feasibility report and programmatic environmental impact statement, variously paged, 4 annexes, 15 apps.

U.S. Fish and Wildlife Service, 2010, Biological opinion on Everglades Restoration Transition Plan, Phase I, November 17, 2010: Vero Beach, Fla., South Florida Ecological Services Office.

U.S. Geological Survey, 2020: EDEN station information data download: Everglades Depth Estimation Network website accessed August 2020, at https://sofia.usgs.gov/eden/data download.php. 



\section{Appendix 1}




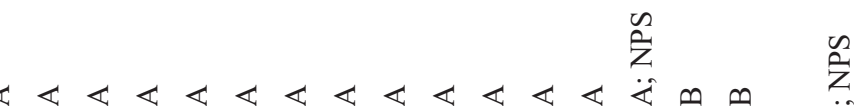

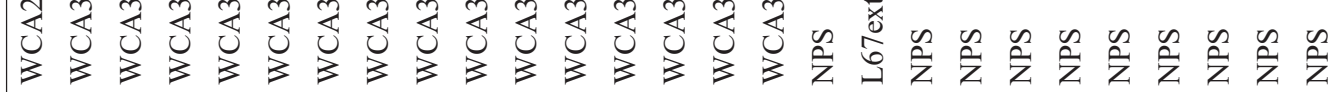

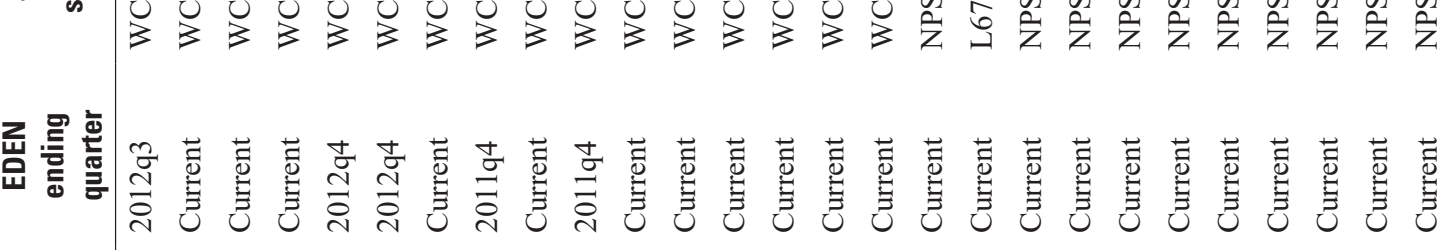

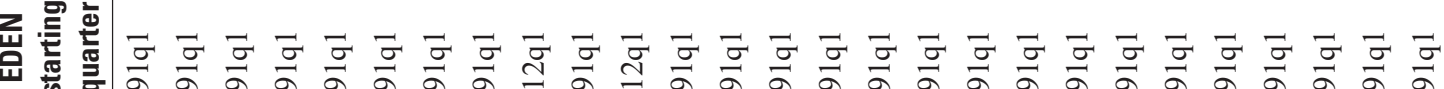

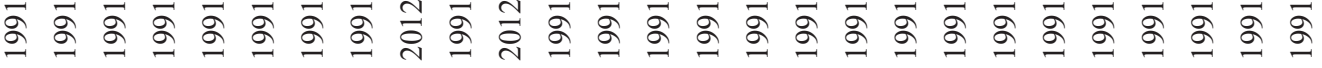

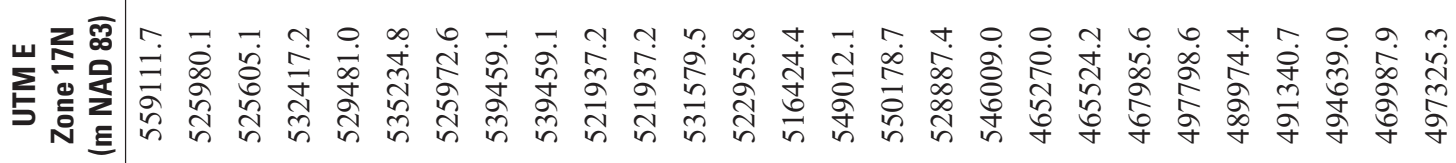
竧

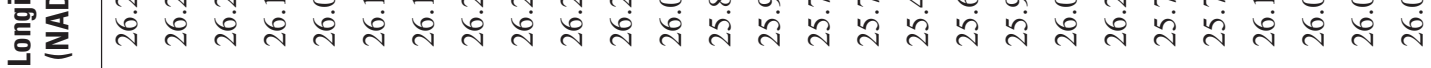

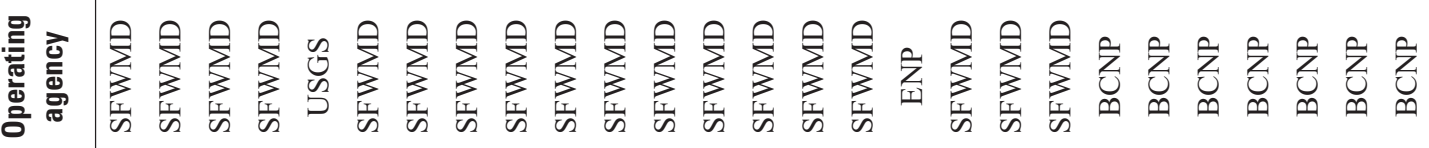
$\sum^{\pi}$ 
毫落高

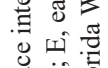

总总語

总

呪

总

范实

을

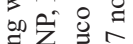

章垈言吉

نें

㷬文

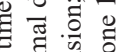

氜

$\exists \sqrt{0}$ 光

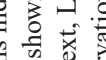

奉苍

क्ष

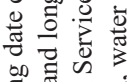

可

氜 导芯

矛焉

加穴营

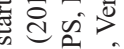

范落

छे क्ष

穴坖范

율 青

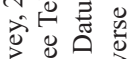

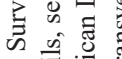

苟苛

웡 娄

吉证

क्रिं

๗

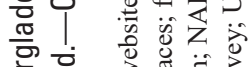

离

등 닌

융

동

宽

बण

힌응

立

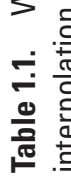

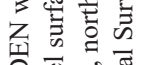

公范范

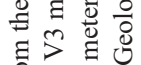

过

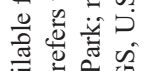

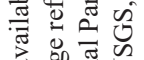

๘

萡

कृ $\frac{0}{0}$

क

幽地

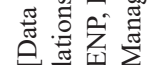

害恣

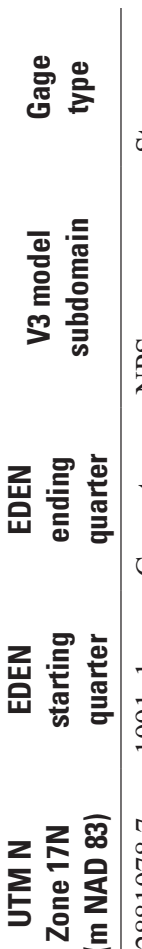

थ $\infty$

दे है थ थ

节

ए

\section{节}

壱

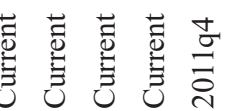

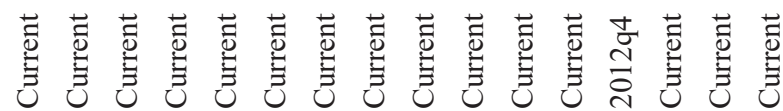

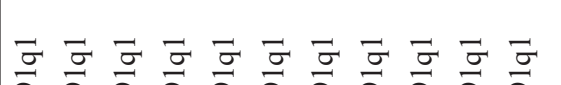

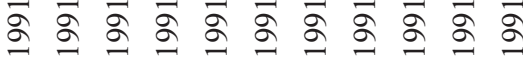

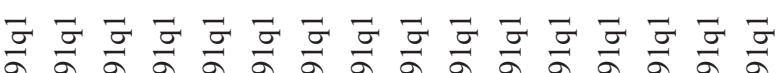

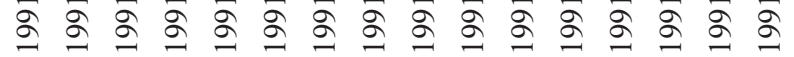

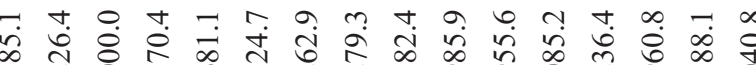

范

ปิ

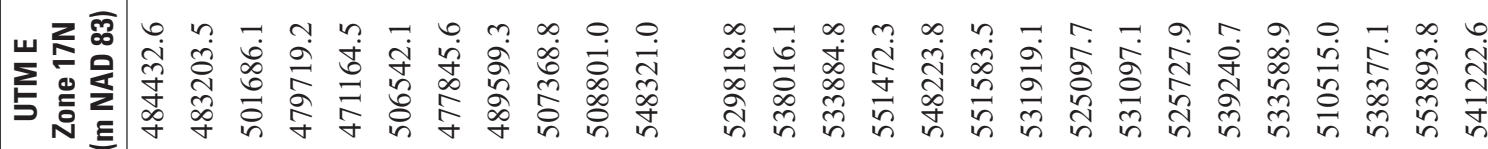

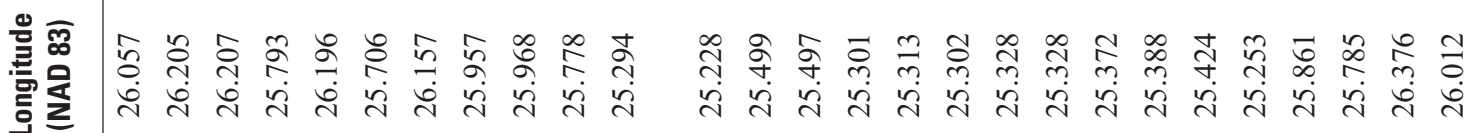

딜

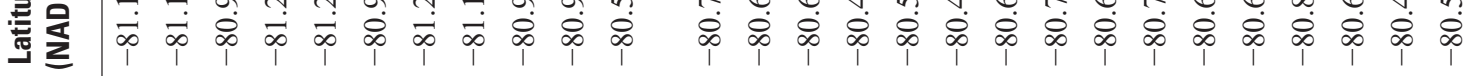

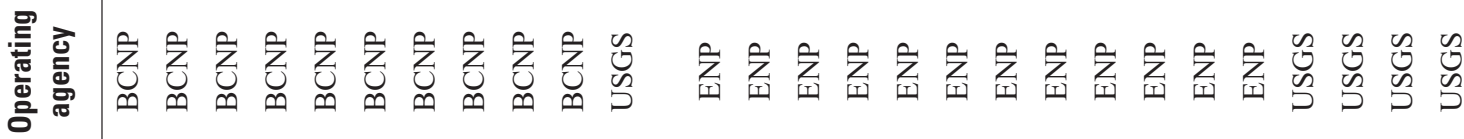

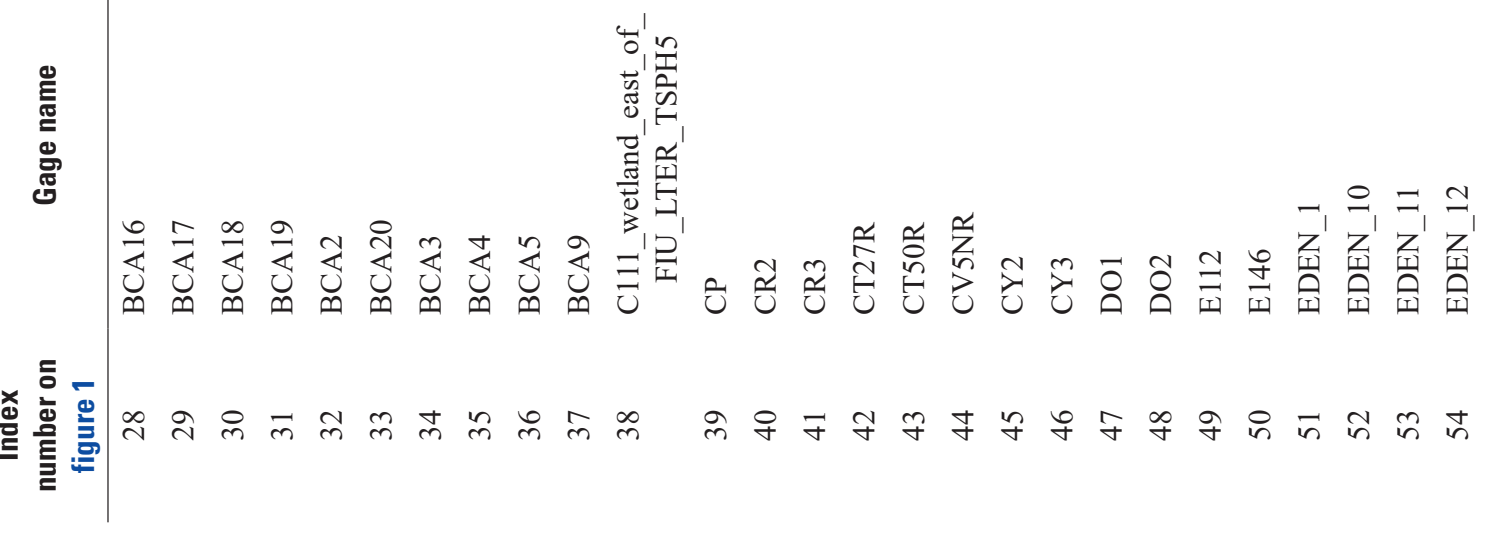




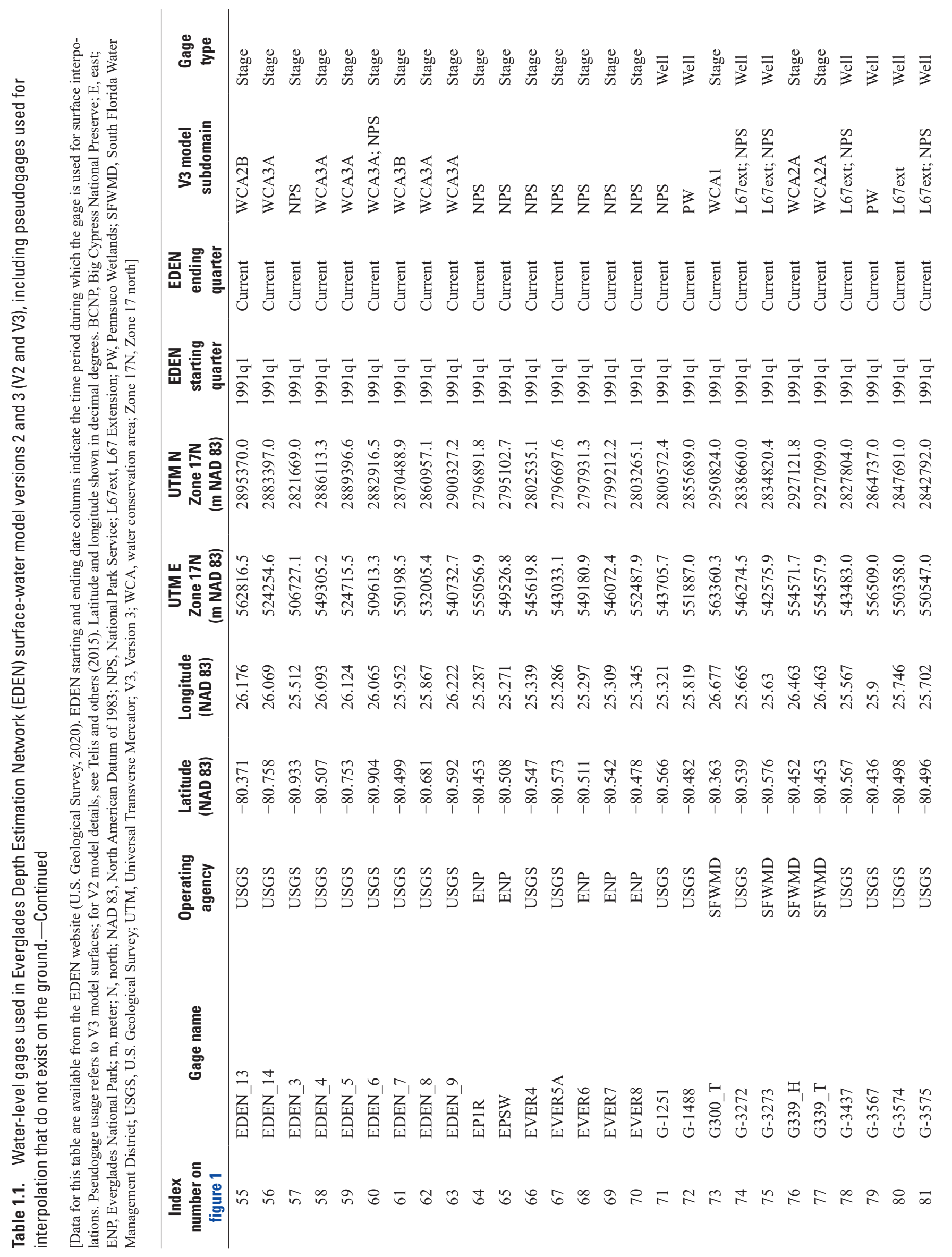




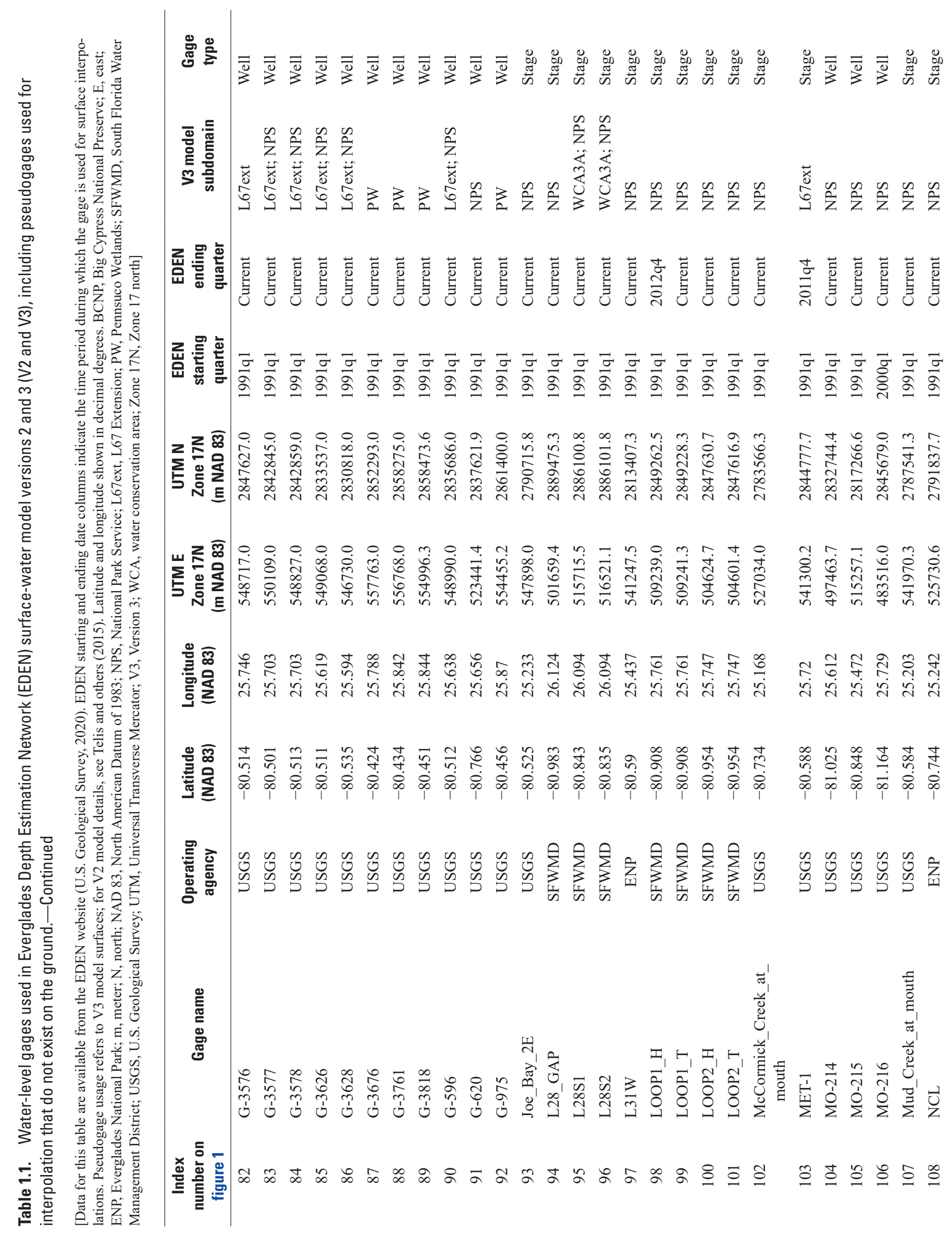




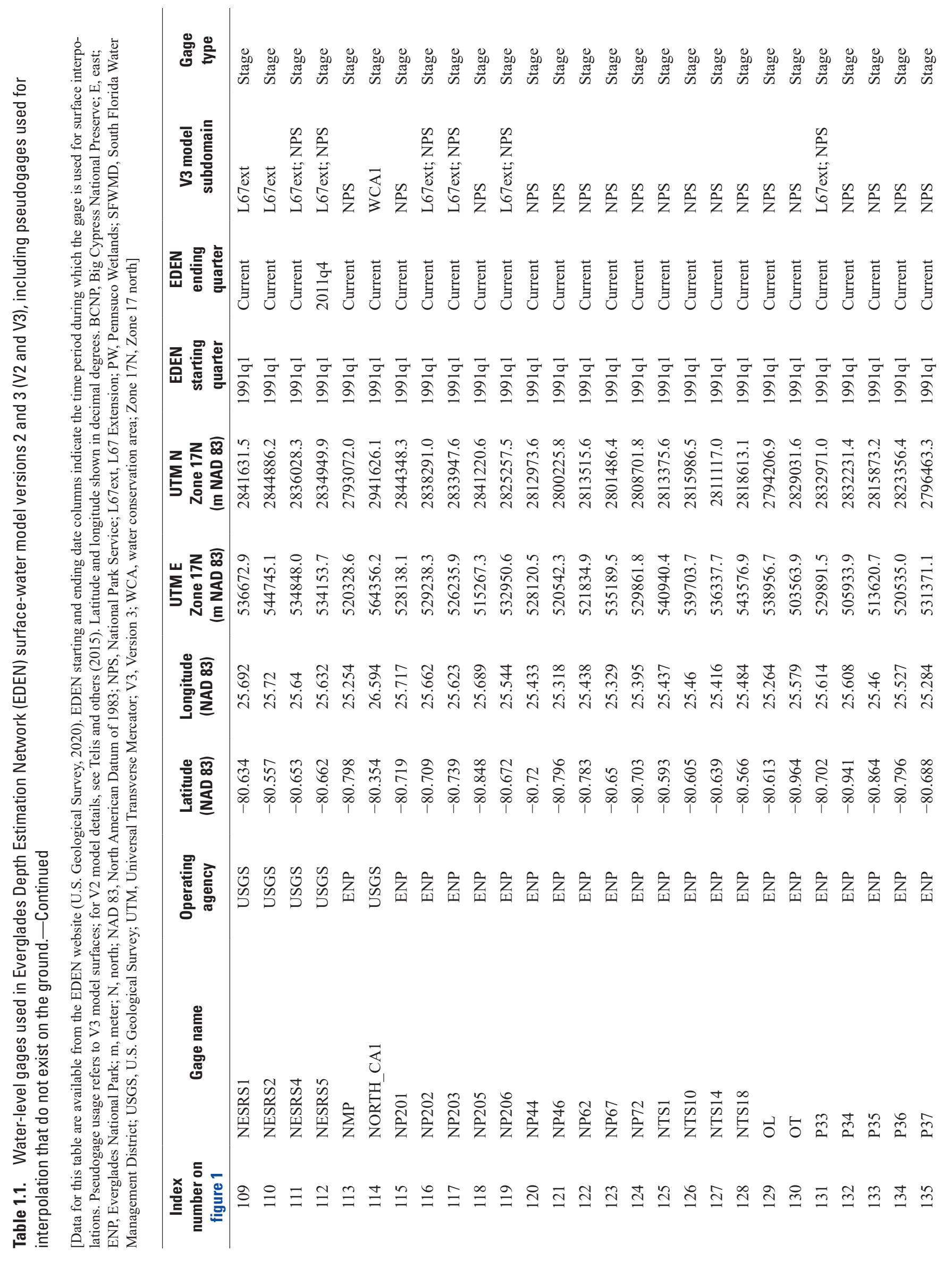




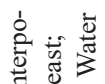

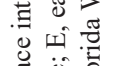

害密定

氙

总

.

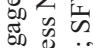

s

.

on $\tilde{Z}$

恶忌言怘

论

它昰

焉

氜㱐

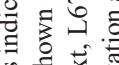

的它

.

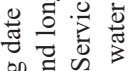

政

记

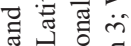

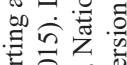

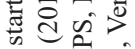

z

जि

记

ते ह

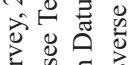

की

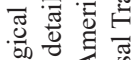

응 항

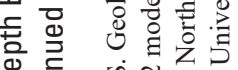

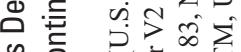

\& 0े

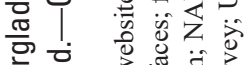

㐫

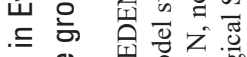

욤

象

离.

열

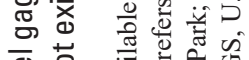

ब

흔 은

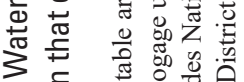

$\therefore$ 든

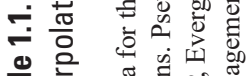

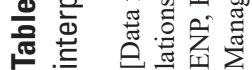

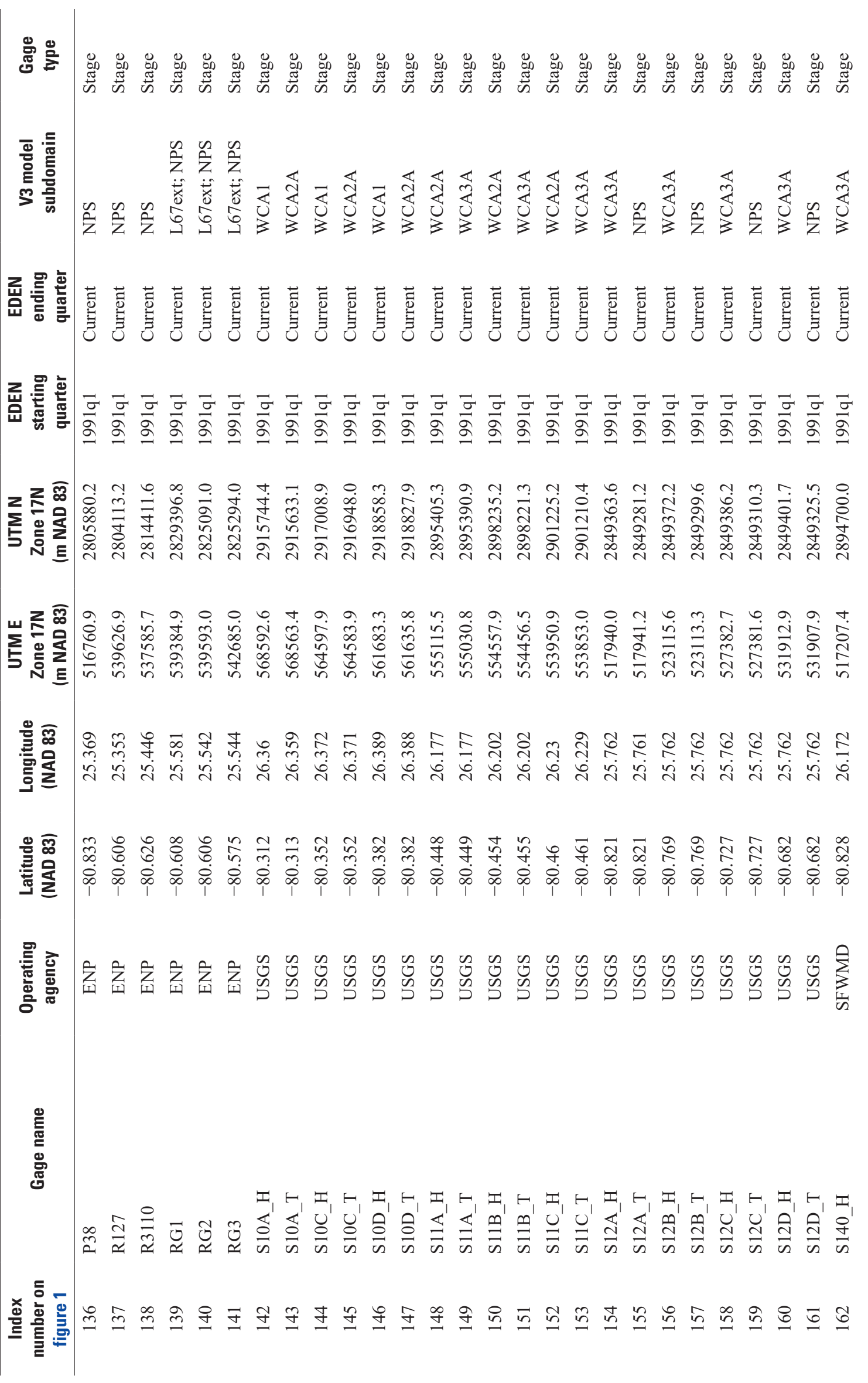




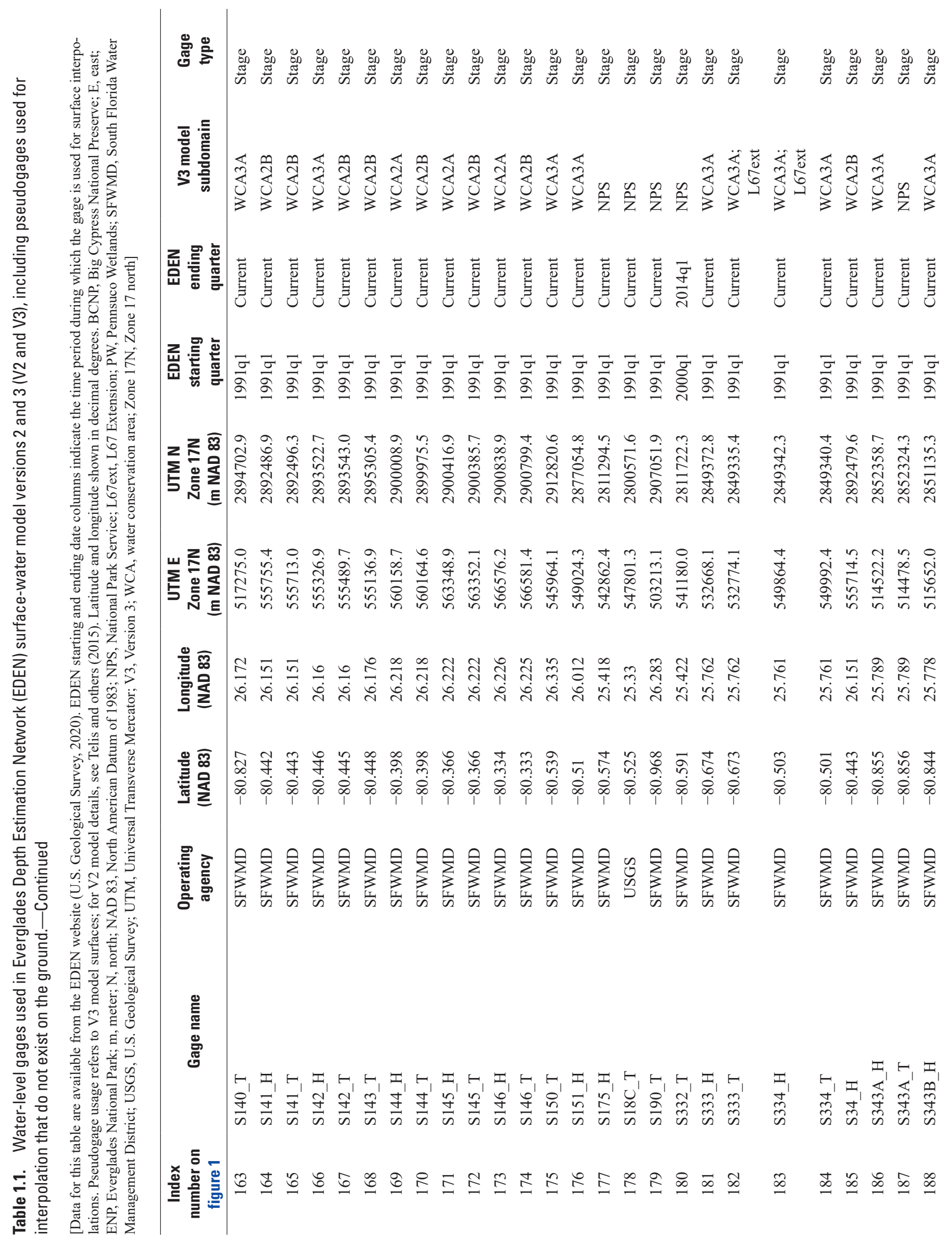


记

茐通

它

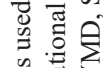

品

政议

‡

酸品竞

oñ 芑

严包言

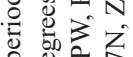

寻泀

正

苞

可

过它

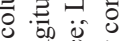

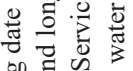

示

远

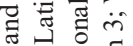

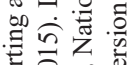

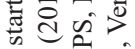

Z

जि

穴坖范

율 青

๙ิట

离的

可

응 눻

들

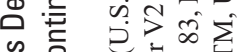

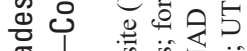

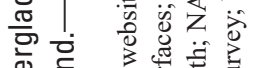

状

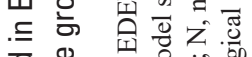

용

๓

岕.

क 요

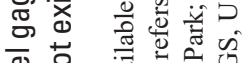

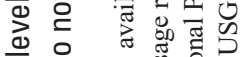

흔

$\sum^{\pi} \stackrel{\pi}{\frac{\pi}{5}}$

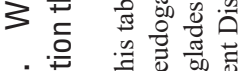

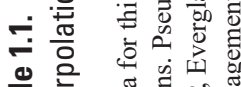

을 잉

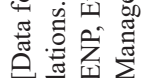

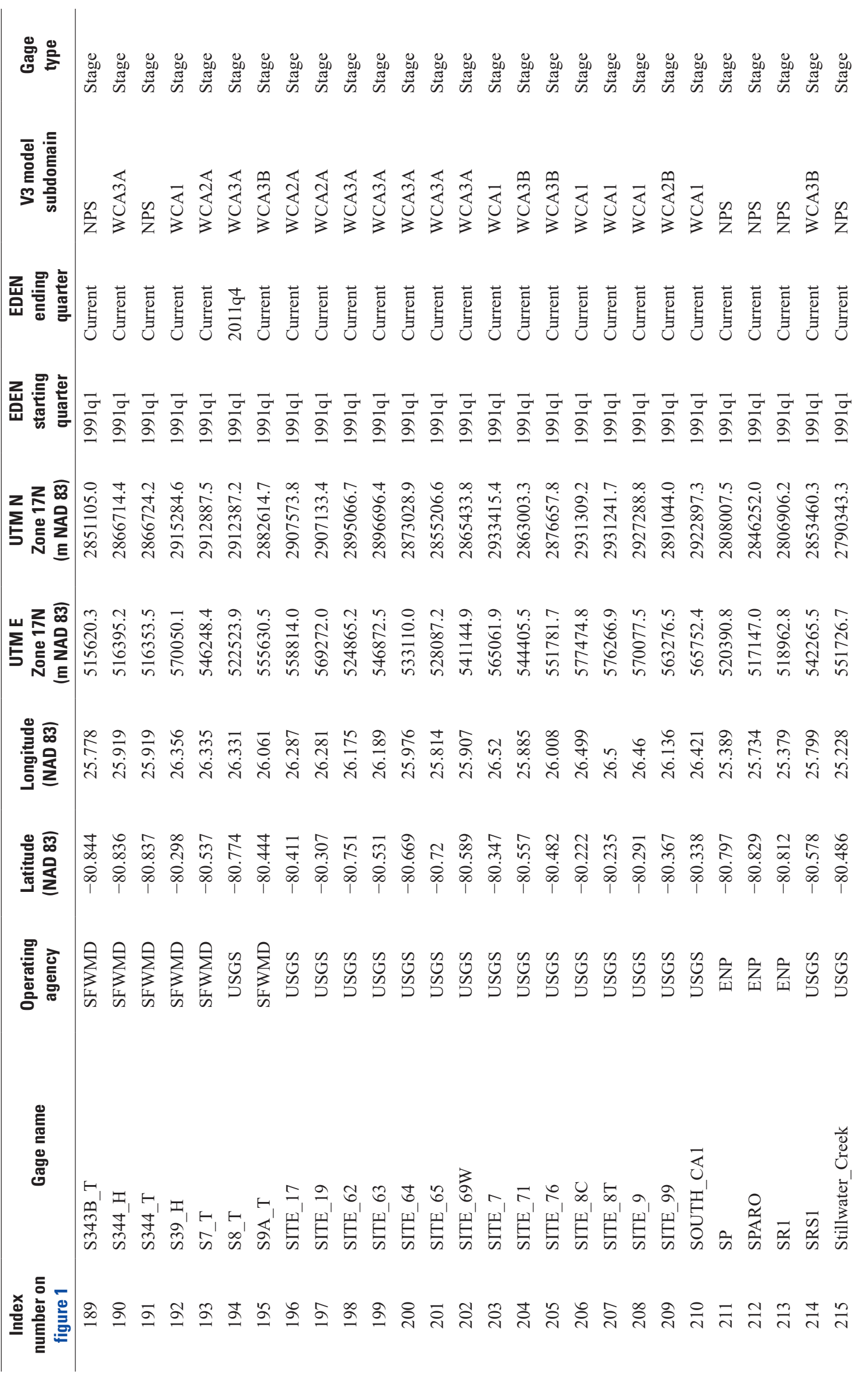




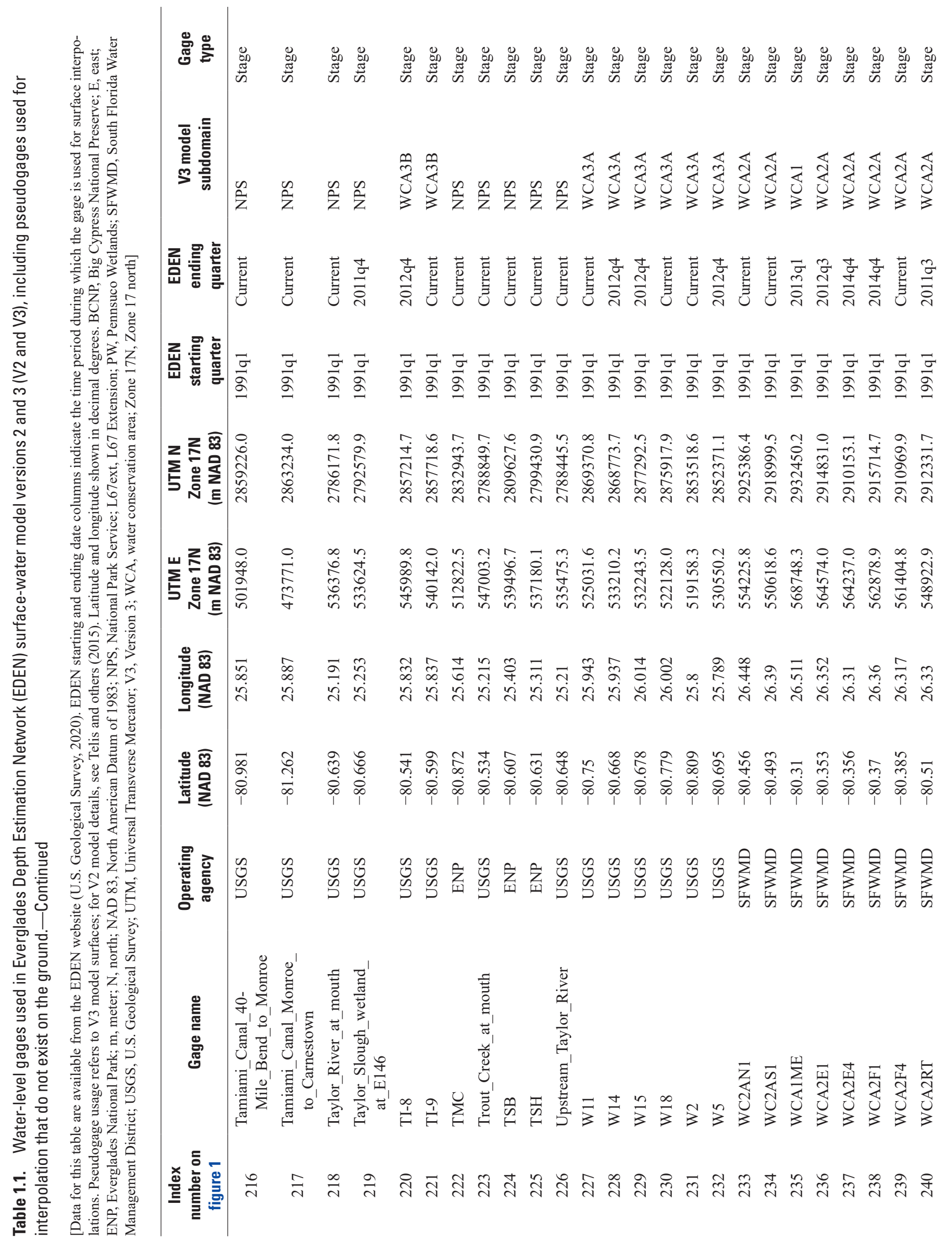




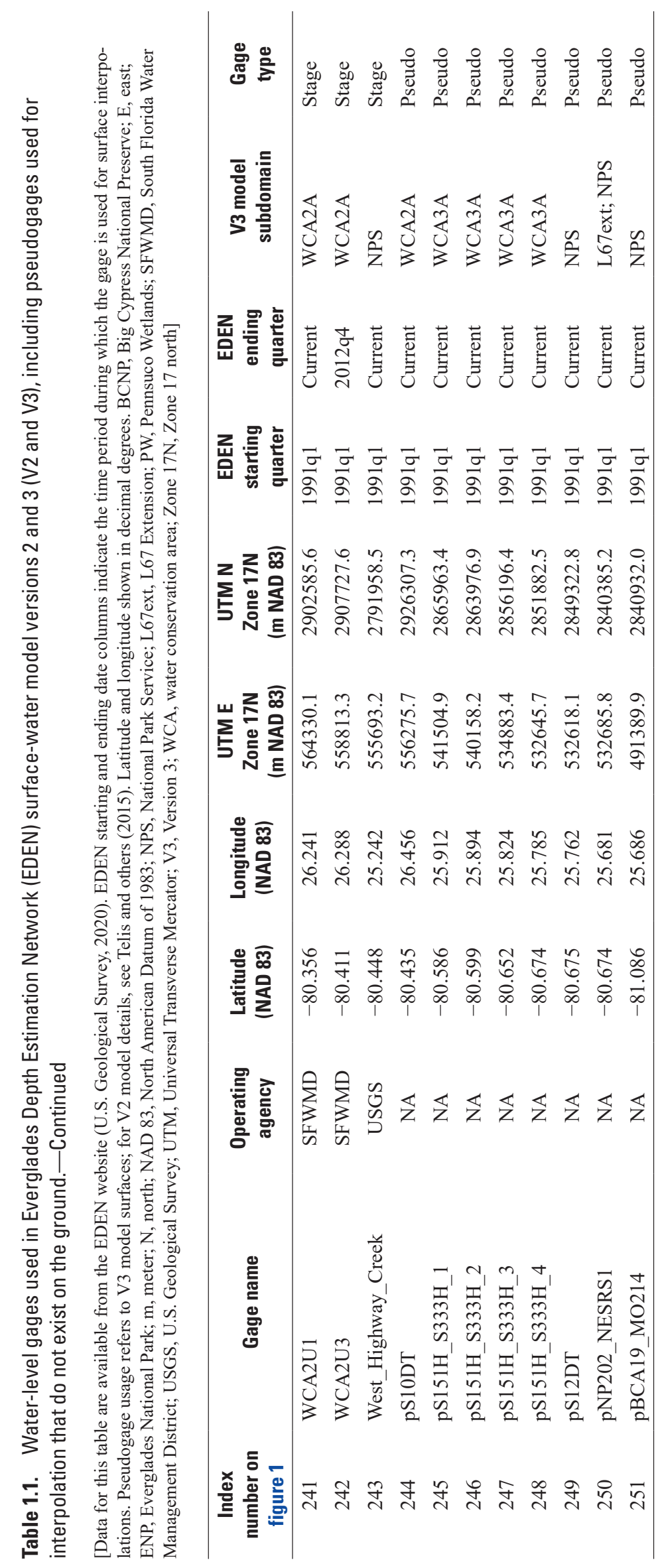



For more information about this publication, contact

Director, Caribbean-Florida Water Science Center

U.S. Geological Survey

4446 Pet Lane, Suite 108

Lutz, FL 33559

(813) 498-5000

For additional information visit

https://www2.usgs.gov/water/caribbeanflorida/index.html

Publishing support provided by Lafayette Publishing Service Center 
